NBER WORKING PAPER SERIES

\title{
GLOBALIZATION, DE-INDUSTRIALIZATION AND MEXICAN EXCEPTIONALISM 1750-1879
}

\author{
Rafael Dobado González \\ Aurora Gómez Galvarriato \\ Jeffrey G. Williamson \\ Working Paper 12316 \\ http://www.nber.org/papers/w12316 \\ NATIONAL BUREAU OF ECONOMIC RESEARCH \\ 1050 Massachusetts Avenue \\ Cambridge, MA 02138 \\ June 2006
}

We are grateful for the excellent research assistant support supplied by David Clingingsmith, Ignacio de la Huerta, Pedro Glaser, Taylor Owings, Rodrigo Parral, and Pablo Tsutsumi. We also have benefitted from help with the data, useful advice and criticism offered by Leticia Arroyo Abad, Luis Bértola, Amilcar Challu, Greg Clark, David Clingingsmith, John Coatsworth, Hector Garcia, Steve Haber, Enrique Llopis, Graciela Márquez, Gustavo Marrero, Javier Moreno, Kevin O'Rourke, Carlos Ponzio, Leandro Prados, Joan Roses, Dick Salvucci and Juan José Urquiola. Dobado is grateful to the Real Colegio Complutense at Harvard, the David Rockefeller Center for Latin American Studies and the Spanish Ministerio de Educación y Ciencia. Williamson acknowledges with pleasure financial support from the National Science Foundation SES0001362 and the Harvard Faculty of Arts and Sciences. The views expressed herein are those of the author(s) and do not necessarily reflect the views of the National Bureau of Economic Research.

(C2006 by Rafael Dobado González, Aurora Gómez Galvarriato and Jeffrey G. Williamson. All rights reserved. Short sections of text, not to exceed two paragraphs, may be quoted without explicit permission provided that full credit, including (๑) notice, is given to the source. 
Globalization, De-Industrialization and Mexican Exceptionalism 1750-1879

Rafael Dobado González, Aurora Gómez Galvarriato and Jeffrey G. Williamson

NBER Working Paper No. 12316

June 2006

JEL No. F1, N7, O2

\begin{abstract}
Like the rest of the poor periphery, Mexico had to deal with de-industrialization forces between 1750 and 1913, those critical 150 years when the economic gap between the industrial core and the primary-product-producing periphery widened to such huge dimensions. Yet, from independence to mid-century Mexico did better on this score than did most countries around the periphery. This paper explores the sources of Mexican exceptionalism with de-industrialization. It decomposes those sources into those attributable to productivity events in the core and to globalization forces connecting core to periphery, and to those attributable to domestic forces specific to Mexico. It uses a neo-Ricardian model (with non-tradable foodstuffs) to implement the decomposition, and advocates a price dual approach, and develops a new price and wage data base 1750-1878. There were three forces at work that account for Mexican exceptionalism: first, the terms of trade and Dutch disease effects were much weaker; second, Mexico maintained secular wage competitiveness with the core; and third, Mexico had the autonomy to devise effective ways to foster industry. The first appears to have been the most important.
\end{abstract}

Rafael Dobado Gonzáles

Department of Economic History

Universidad Complutense Madrid

Somosaguas Campus

Madrid 28223

SPAIN

rdobado@ccee.ucm.es

Aurora Gómez Galvarriato

Division of Economics

CIDE

Lomas de Santa Fé 12010

México DF

MEXICO

aurora.gomez@cide.edu

Jeffrey G. Williamson

Department of Economics

Harvard University

Cambridge, MA 02138

and NBER

jwilliam@fas.harvard.edu 


\section{Mexico and the Great De-Industrialization Debate}

The economic impact of the core on the periphery between 1750 and 1913 had its source in three forces. The first was a European policy movement away from anti-global mercantilism and towards pro-global free trade (Findlay and O'Rourke 2003). The second was a world-wide transport revolution that served to further integrate world commodity markets $(\mathrm{O}$ 'Rourke and Williamson 1999: Ch. 3; Mohammed and Williamson 2004; Williamson 2006b: Chs. 2 and 3). It caused a boom in trade between core and periphery, created commodity price convergence for tradable goods between all world markets, and contributed to a rise in every country's external terms of trade, especially in the periphery. The third came from the derived demand for industrial intermediates, like cotton, rubber and metals, which soared as manufacturing production led the way in the core. Thus, as core economies raised their industrial output shares, manufacturing output growth raced ahead of GDP growth. Rapid productivity growth lowered the cost and price of manufactures, and by so doing generated a soaring derived demand for raw materials. This event was reinforced by accelerating income per capita growth and a high income elasticity of demand for luxury consumption goods, like meat, tea, and coffee. Since industrialization was driven by unbalanced productivity advance favoring manufacturing relative to agriculture and other natural-resource based activities, the relative price of manufactures fell everywhere. The world transport revolution made it possible for the distant periphery to supply this booming demand for primary products. All three forces produced positive, powerful and sustained terms of trade shocks in the periphery, raising the relative price of primary products, and through an epoch which stretched over a century. Factor supply responses in the periphery facilitated these external demand shocks, reinforcing their comparative advantage in primary products and causing deindustrialization. 
Eventually these three forces abated. A globalization backlash hit most of the world (except Britain, the Netherlands, and their colonies), causing a partial shift backwards to protection (Williamson 2006a). The rate of decline in real transport costs along sea lanes slowed down, approaching a late $20^{\text {th }}$ century steady state (Mohammed and Williamson 2004). The rate of growth of manufacturing slowed down in the core as the transition to industrial maturity was completed. As these three forces abated, the resulting slow down in primary product demand growth was reinforced by resource-saving innovations in the industrial core, induced, in large part, by those high and rising primary product prices during the $19^{\text {th }}$ century terms of trade upswing. Thus, the secular boom faded, eventually turning into a secular bust. Exactly when and where the boom turned to bust depended on export commodity specialization, but all periphery regions reached a terms of trade peak somewhere between the 1870s and World War I.

This secular boom in the periphery terms of trade is illustrated well by Latin America. The region's terms of trade underwent a steady increase from the 1810 s to the early 1890 s, and the improvement was especially dramatic during the first five decades. Furthermore, the increase is understated to the extent that it fails to take account of the likely quality improvement in traded manufactures relative to primary products: the quality-adjusted terms of trade in Latin America probably grew at a little more than 2.2 percent per annum between $1815-19$ and $1855-59$, and at a little more than 1.4 percent per annum between 1815-19 and 1890-94 (Williamson 2006b: Figure 1 and Appendix 1). This was a very big terms of trade boom, but Latin American experience was hardly unique since the increase was even bigger for Egypt, the Ottoman Empire (Turkey), Japan, Indonesia, and elsewhere in the periphery.

During the terms of trade boom, rates of technological advance and human capital accumulation were so modest in the periphery that the living standard gap between it and the core surged to levels that were vastly wider at the end of the boom than at the beginning. Whether the modest rates of technological advance and human capital accumulation in the periphery were caused by de-industrialization has, of course, been a central issue in historical debate since it all 
started. What all scholars agree on, however, was that the terms of trade boom caused deindustrialization in the periphery through Dutch disease and other effects.

This paper establishes that Mexico obeyed the same laws of motion between 1750 (just before the Bourbon reforms) and 1879 (before the economic changes of the Porfiriato began). However, the differences between Mexico and the rest of the poor periphery were sufficiently pronounced to allow us to speak of Mexican exceptionalism. The rate of de-industrialization was far less than elsewhere in the periphery, suggesting that there were local forces at work that distinguished Mexican experience from the rest. Section 2 places de-industrialization within Mexican growth experience over almost two centuries after 1700. Section 3 describes Mexican de-industrialization and industrialization over more than a century before the Porfiriato. Section 4 presents a three-sector neo-Ricardian model with two tradables (silver exportables and textile importables) and one non-tradable (corn) which makes it possible to sort out the role of external terms of trade booms and local wage competitiveness. The remainder of the paper uses the model to decompose the sources of Mexican exceptionalism with de-industrialization. It turns out that there were three forces at work: first, the terms of trade and Dutch disease effects were weak compared with the rest of the periphery (Section 5); second, Mexico maintained better wage competitiveness vis a vis the core compared with the rest of the periphery, a result determined by relative productivity performance in food production (Section 6); and third, Mexico had the autonomy - something that most of the poor periphery did not - to devise effective policies to foster industry (Section 7). The first appears to have been the most important of the three.

\section{Placing Mexican De-Industrialization in the Transitional Century Before 1879}

It is very important to distinguish between economy-wide productivity levels and rates of growth, on the one hand, and industrial output and employment performance, on the other. This section starts with the former before dealing with the latter. 


\section{Mexican Economic Growth: Bourbon Reform, Insurgencia and Lost Decades}

In 1765, the Spanish government endorsed the Decree of Free Trade, by which restrictions regulating commerce between Spain and Spanish America were substantially modified. A century later, the Porfiriato (1876-1910) began to open Mexico to the global economy even further. In both cases, these liberal policies were followed by economic growth. But they also contributed to a rising inequality ${ }^{1}$ which helped provoke widespread social discontent, the Insurgencia that started in 1810 and the Revolution that started in 1910. The two movements generated immense violence, and they had much to do with the ending of Spanish colonial rule in one case and the Porfiriato in the other.

Debates about colonial growth have been lively, mostly because the evidence is so scarce. Still, an optimistic view is on the rise (Klein 1998; Dobado and Marrero 2001, 2005; Ponzio 2005a). Mexico produced two thirds of total world silver output by 1800 and most of it was exported to an expanding international economy. In addition, while Mexican GDP per capita may have been lower than that of the western European core (Maddison 2003), it was higher than many in the European periphery (like Greece and Russia), and similar to others. Furthermore, Mexico was well ahead of Asia and Africa. There is, of course, a more pessimistic view, such as that of John Coatsworth (2003, 2005). The estimates offered by Coatsworth and Angus Maddison (Table 1) epitomize the two views of Mexican $18^{\text {th }}$ century economic performance. Coatsworth's pessimism emerges from his documented stagnation between 1700 and 1800, followed by the economic disruption caused by Insurgencia. Maddison's optimism emerges from his substantially lower GDP per capita estimate for 1700, and, apparently, the belief that economic disruption during Insurgencia had no lasting impact. Note, however, that both authors document a significant increase in Mexico's GDP during the $18^{\text {th }}$ century: Maddison estimates a doubling

\footnotetext{
${ }^{1}$ Evidence of rising inequality is suggested by the significant fall in Mexican grain wages from 1750 to the 1820s (Figure 7). However, workers' living standards failed to rise in many parts of the world in the late $18^{\text {th }}$ and early $19^{\text {th }}$ centuries (Allen et al. 2005), so their fall in Mexico is hardly unique and may be driven by a shared event, like climate change.
} 
between 1700 and 1820, while Coatsworth estimates an increase by 2.3 times between 1700 and 1800. Thus, the difference in their per capita GDP growth estimates lies with very different views about population change. ${ }^{2}$ In any case, Maddison (2003) estimates that Mexican per capita GDP was about $77 \%$ of the continental European periphery in $1820 .^{3}$

Debate over GDP per capita growth before 1820 will, no doubt, continue, as will debate over relative GDP per capita levels at the start of the $19^{\text {th }}$ century. But there is other evidence supporting significant economic achievement of the $18^{\text {th }}$ century Mexican pre-industrial economy. For example, the share of the population urban was at least $9.1 \%$ around $1800 .{ }^{4}$ This 1800 urbanization rate was higher than that of Scandinavia, Ireland, Germany, France, Switzerland, Portugal, Austria-Hungary and Poland, almost equal to Spain (11.1\%), and very close to the European 10\% average (de Vries 1984: Table 3.8; Williamson 1990: Chp. 1). Growing towns implied declining agricultural self-sufficiency, rising commercialization, developing internal markets, and an industrial base equivalent to the proto-industrial platform from which Germany, France, Switzerland and so much of the rest of the European continent was to develop their industrial revolutions between 1800 and 1870. It appears that Mexico was not able to exploit that same urban-industrial base over those years.

While the debate about Mexican growth before the Insurgencia may be intense, there is little disagreement with the view that the Mexican economy did not grow between the Insurgencia and the start of the Porfiriato in 1876. Coatsworth (2003) documents a decrease in per capita GDP between 1800 and 1877, from 755 to 642 international dollars of 1990. Indeed, during the five lost decades from 1820 to 1870, the per capita GDP growth rate ranged between $-0.2 \%$ (Maddison) and $+0.3 \%$ (Coatsworth), for an average of about no growth at all (Table 1 )

\footnotetext{
${ }^{2}$ Maddison estimates a $0.32 \%$ annual rate of population growth, while Coatsworth estimates $0.73 \%$. Obviously, further research on the demographic aspects of $18^{\text {th }}$ Mexico is needed to resolve this immense difference.

${ }^{3}$ The "continental European periphery" is here taken as the unweighted average of Czechoslovakia, Denmark, Finland, Italy, Norway, Spain, Sweden and Russia.

${ }^{4}$ Calculated from cities with 10,000 inhabitants or more reported in Humboldt (1984) circa 1800.
} 
These Mexican 'lost decades' took place when the European and North American economies were undergoing industrial revolutions and showing features of vigorous modern economic growth. Even when compared with slow-growing $19^{\text {th }}$ century Spain, Mexico underperformed. ${ }^{5}$ Most analysts of the poor economic performance during the 'lost decades' point to institutional and political instability (Ponzio 2005b). Others would, no doubt, emphasize the legacy of inefficient colonial institutions (Acemoglu et al. 2002; Coatsworth 2005), inequality (Engerman and Sokoloff 1997), and culture (Harrison 1985; Landes 1998). Still others believe that it was an interruption of colonial "mining led growth" that was central to the underperformance of the Mexican economy after the Insurgencia (Dobado and Marrero 2001, 2005).

The important point here is that the rising economic gap between Mexico and western Europe between 1800 and 1870 was largely the result of the Insurgencia and the postindependence lost decades, not just colonial legacies. After all, by 1800 or 1820 Mexico had achieved almost the same level of development as the industrial late comers in continental Europe.

\section{Foreign Trade and Openness}

Commerce between Spain and Spanish America was strictly regulated until 1765. Only one port in Spain - Cádiz -- and four in America -- Cartagena, Portobelo, Santo Domingo and Veracruz -- were authorized to trade. The rationale for this system was to insure that the Crown could collect (heavy) taxes on trade with its colonies. Early in the $18^{\text {th }}$ century, some observers claimed that the trade regulations actually did not favor the Crown since they limited commerce and thus the tax potential. Lower taxes, more ports, fewer smugglers and a pro-growth policy would, it was argued, increase revenue for the Crown. Eventually, the Crown listened and

\footnotetext{
${ }^{5}$ According to Maddison's (2003) estimates, the ratio of Spanish to Mexican per capita GDP decreased between 1700 and 1820 (from 150 to 133), but rose between 1820 and 1870 (from 133 to 179).
} 
colonial trade was liberalized. By 1789, New Spain was given full access to the new liberal system; colonial Mexico went more open.

Figure 1 offers estimates of late colonial openness, and it also extends the measure to the late $1860 \mathrm{~s}$. As is common in the trade-development literature, the openness variable is simply the trade share, that is, exports plus imports as a share of GDP. The average trade share was $9.6 \%$ between 1796 and $1820,12.5 \%$ between the mid 1820 s and the mid $1850 \mathrm{~s}$, and $17 \%$ by 1872 . The 1796-1820 trade share was higher than that of France in 1815, 8.4\% (Mitchell 2003: 571 and 905), and comparable to the US. Thus, the late colonial and the early post-colonial Mexican economy was open by the standards of that time.

Furthermore, the structure of Mexican foreign trade with the Atlantic economy can be summarized (Table 2) without much exaggeration as an exchange of silver, augmented by cochineal dye ${ }^{6}$ for textiles. Pacific trade with Asia was similar, mainly consisting of textile (and handicraft) imports and silver exports through the Galeón de Manila. Independence did not bring about a substantial change in the structure of the Mexican foreign trade, dictated as it was by fundamental resource endowments and geographical location. Indeed, export specialization was reinforced, and textiles kept their dominant position among imported items. The textile import share in total imports was $64.8 \%$ in the decade before ${ }^{7}$ the Insurgencia and $63.4 \%$ in the decade thereafter. Machinery and tools were virtually zero in the 1820 's, but these imported capital goods rose as Mexico resumed growth and accumulation at the end of the lost decades. ${ }^{8}$ Still, Mexico's $19^{\text {th }}$ century foreign trade mix was much like that of the colonial period -- silver in exchange for textiles. Thus, Mexican import capacity depended on silver exports and silver production. Since silver production fell from late colonial levels and underwent only a slow and

\footnotetext{
${ }^{6}$ Between 1796 and 1828, export values of cochineal ranged between 4 and $38 \%$ of total exports, and averaged more than 15\% (Baskes 2005: 192-3).

${ }^{7}$ The average excludes the years 1805-6 and 1809, when international hostilities sharply reduced Atlantic trade.

${ }^{8}$ Using a new series for machinery investment, Luis Catão (2006: Table 6) estimates an impressive accumulation surge between 1874 and 1906, most of it industrial based.
} 
incomplete recovery after independence, import capacity rose only slowly as well, such that textile imports did not recover their pre-Insurgencia peak. In short, there was no export-led growth boom until the Porfiriato. Was it because the world price of silver was fixed? Was it because the Spanish mercury subsidy (for silver extraction) evaporated? Was it because of other Mexican supply-side factors?

In any case, when Porfirio Diaz rose to power, Mexican per capita income probably had not risen above its 1820 level. Yet, the economy was more open, the signs of an economic boom were clearly visible, political stability had finally been achieved, and economic modernization was about to begin.

\section{De-Industrialization and Industrialization in Mexico}

Textiles are a very big share of manufacturing activity in all economies starting modern economic growth, whether the gauge is employment or output. Fortunately, it is also the best documented sector. Thus, our account of Mexican de-industrialization and industrialization over the two centuries before 1879 will focus on woolens and cottons.

\section{Domestic Textiles and Industry Before 1820}

The post-conquest Mexican textile industry began as early as the 1530 s with the establishment of the first obrajes, integrated woolen textiles manufactories with from twenty to one hundred workers. Richard Salvucci (1992: 222-3, 237) estimates that obraje production rose from about 1.5 million pesos in 1600 to between 1.5 and 2 million pesos in 1700 . Woolen textiles underwent a sharp secular decline late in the colonial era, so that by the end of the $18^{\text {th }}$ century production had decreased to between 1 and 1.5 million pesos, and was negligible by 1812 . The obrajes heyday had passed by the 1810s. While 40 obrajes were operating in New Spain in 1579, 
there were only 30 in 1770 , and 19 in $1810 .{ }^{9}$ Increasingly, woolen textile production was carried out in domestic workshops (trapiches) which "expanded in Querétaro from 30 to 340 between 1693 and 1803" (Salvucci 1992: 211). The switch from obrajes to trapiches was part of a cost reducing response to the inflow of cheap foreign cloth, reflected by a steep decline in the price of textiles relative to corn (Figure 6). After 1750, obrajes not only had to face increasingly fierce competition from British and Catalan cloth (Salvucci 1992: 234), but also from growing Mexican cotton textile production. While foreign cotton goods certainly penetrated the Mexican market, domestic cotton textile firms fared better than did obrajes in the competition. Cotton textiles expanded in New Spain between 1750 to 1800 , and by the end of the century cotton production was far more important than woolens. Manuel Miño has estimated that there were around 11,000 Castillian treadle looms working in New Spain by 1800 , of which $87 \%$ were weaving cotton (Miño 1983: 583).

Cotton textile production was based on a putting-out system similar to that which flourished in pre-industrial Europe. Merchants distributed raw cotton to artisans who did the spinning and weaving, after which these merchants (exploiting their commercial networks) sold the finished product throughout the region, sometimes as distant as what we now call New Mexico. This expansion took place most prominently around the cities of Puebla, Tlaxcala, Mexico, and Guadalajara (Miño 1998: 79-107; Miño 1993: 170). ${ }^{10}$

Cotton textile production diversified in the second half of the $18^{\text {th }}$ century, evolving from the production of only basic cotton drill (manta) to calico prints (indianas, pintadas or zarazas: Thomson 1991: 259). Several indianilla factories were established in New Spain which

\footnotetext{
${ }^{9}$ Obrajes expanded from 1570 to 1630 mostly in the Puebla-Mexico City region. The prohibition of international trade that cut off the Peruvian market meant great difficulties for the industry. Thereafter, production moved to the Querétaro area where wool was more abundant (Miño 1998: 30-1).

${ }^{10}$ As cotton production expanded, guilds began to appear in the different cities, the earliest dating from 1686 in Puebla. Yet, they were never as important as in Europe since the guild order never encompassed Indian workers, the most important workforce in New Spain. Moreover, most weavers in these guilds were dependent on merchants in the putting-out system. Although guilds were formally abolished by a decree in 1813, they continued to exist until 1820 (Miño 1998: 89; Thomson 2002: 163-176).
} 
specialized in printing, and finishing cotton yarn and cloth produced by the domestic putting-out system or imported from China and India (Miño 1998: 186-7). These factories were similar to those that were being developed in Catalonia, and they represented the most elaborate manufacturing organization that had yet appeared in the New Spain (Miño 1998: 185-193). It is not clear how many of these factories existed, but there appear to have been several producing cloth of "a certain most delicate luxury" (Humboldt 1822: 451). Records exist for an indianilla factory in Mexico City which document that by 1804 it held a capital of 13,942 pesos, ${ }^{11}$ and employed close to 500 workers (Miño 1998: 191).

Although obrajes underwent a steep secular decline throughout the $18^{\text {th }}$ century, total textile production expanded. The number of looms in New Spain increased from 1,323 in 1781, to 9,981 in 1793 and 11,692 in 1801 (Miño 1998: 285-7), providing work for approximately 90,000 spinners and weavers in 1800 (Thomson 1991: 258). Miño (1998: 244) estimates that cotton textile production must have been a little more than 5 million pesos by the end of the $18^{\text {th }}$ century, or between 60 and $70 \%$ of total manufacturing production in New Spain, which ranged from 7 to 8 million pesos (Humboldt 1822: 451).

During the years preceding the Peace of Amiens (1796-1801), cotton textile manufacturing in New Spain flourished given the relative absence of European imports cut off by wartime conflict (Thomson 1991: 260, 2002: 84-5). The good times ended after 1802, however, when Spanish policy allowed neutral powers to trade directly with the Indies triggering an invasion of foreign cloth (Miño 1998: 266-7). Between 1806 and 1818, textile imports were 85\% of the total imports (Thomson 2002: 105). From 1802 to the 1830s, Mexican textiles faced the most intense foreign competition they had ever experienced.

The war of Independence (1810-1821) raised de-industrialization forces to "apocalyptic" proportions (Miño 1998: 270). The violence hit hardest those regions in which the textile industry

11 This is bigger than the 10,400 pesos capital for the largest obraje in New Spain, Tacuba in 1752 (Miño 1998: 48). 
was located, Bajío and Puebla-Tlaxcala. Raw materials became scarce, and the commercial routes to the north, traditionally an important market for domestic textile production, were cut. Mortgage registries from the city of Puebla show that from 1816 to 1820 private lending decreased considerably and clerical lending collapsed completely (Thomson 2002: 96). Many textile workers abandoned their looms to join the contending armies and many died as a consequence of epidemics (Salvucci 1992: 238; Miño 1998: 269-72; Thomson 2002: 245). The Insurgencia delivered the death blow to obrajes. There were still 19 obrajes with 291 looms operating in Querétaro in 1810, but only 4 were still working in 1812. By 1831, the looms in Querétaro were producing only 1200 pieces of woolen cloth yearly, compared with 7000 pieces produced there at the end of the $18^{\text {th }}$ century.

Cotton textile production was also greatly affected. The Consulate of Mexico reported that in 1818 foreign trade had left 12,000 formerly employed in textile production unemployed (Miño 1998: 269). The city of Puebla, where an important part of the cotton cloth industry was located, experienced a population decrease of $19 \%$ from 1791 to 1821 , most of which took place during Insurgencia (Thomson 2002: 244-5). Guadalajara's cotton textile production “was virtually eliminated by competition from imports through the newly opened Pacific ports" (Thomson 1991: 275). Some cotton cloth production survived the Insurgencia, but the sector did not recover until the 1830s. As Guy Thomson (1991: 260) points out, Mexican domestic textile production suffered through more than three decades of hard times, partly due to the short run effects of Insurgencia and partly due to long run effects of foreign competition.

Although the literature does not document the evolution of Mexico's woolen textile sector in great quantitative detail, it does offer several competing explanations for its demise. Salvucci (1987) favors domestic demand and closed economy thinking. His argument is that woolen textiles were an inferior good: as household incomes and living standards rose, consumption and thus production of obrajes fell. But, as we saw in Section 2, it is not clear that Mexican income per capita actually rose in the 18th century. When Salvucci was writing, he used 
silver output as a proxy for income. But given the more recent evidence of population growth, modest increases in per capita income, and real wage decline (Figure 7), it is hard to remain sympathetic with Salvucci's demand-led hypothesis. In any case, since the logic of Salvucci's demand-led hypothesis requires that New Spain be viewed as a closed economy, it must be rejected. ${ }^{12}$ Colonial Mexico certainly wasn't a closed economy. Indeed, Salvucci himself appears to acknowledge that fact when he notes the importance of contraband cloth entering from the West Indies during the $18^{\text {th }}$ century to explain the troubles obrajes faced. As we argued in Section 2 (see Figure 1), New Spain was a relatively open economy. If the economy really was closed, and if, therefore, domestic demand really mattered that much, we ought to see a rise in the relative price of cotton cloth relative to woolens across the 18th century. We do not. Mexico mimics world relative cloth price trends, and they certainly do not confirm Salvucci's hypothesis. Instead, relatively rapid productivity events in cotton spinning and weaving abroad served to drive down the relative price of cotton goods. In an open economy like colonial Mexico, domestic demand may have influenced trade volumes, but it did not influence the relative price of goods actively traded in world markets. Imported factory goods were competing with Mexican spinning and weaving, and such competition was hardly unique to Mexico since it was also taking place in India (Clingingsmith and Williamson 2005), the Ottoman Empire (Pamuk 1987; Williamson and Yousef 2006) and elsewhere in the poor periphery (Williamson 2005, 2006b). The evidence also suggests that, like Mexico, there was no significant increase in Indian and Ottoman per capita income which might have had the local demand affects Salvucci hypothesizes.

Brian Hamnett (1980) offers another demand-led hypothesis. He thinks that the fall of wool production prior to the wars for independence was linked to an agrarian crisis and the resulting collapse in purchasing power. In his view, a rise in the price of maize increased the price of all other cereals, which in turn put upward pressure on food costs more generally. This served

\footnotetext{
${ }^{12}$ It should be added that Salvucci was writing in the 1980s when ISI and closed economy models were still the mainstream. We are writing twenty years later when supply-side models have become mainstream.
} 
to reduce household surplus available for other goods like textiles, causing a fall in textile demand and a decrease in obraje output. ${ }^{13}$ Since later in this paper we document a large decline in real wages up to independence (Figure 7), we agree with the first step in Hamnett's argument. However, we do not agree with the last step. We have already argued that domestic demand could not have played anything but a modest role between 1750 and 1820. In addition, the rise in food costs that Hamnett cites (and we confirm in Figure 5) is likely to have put upward pressure on the nominal wage and thus served to reduce competitiveness in domestic textiles: labor costs rose while output prices fell. We shall return to these supply-side forces emanating from the 'agrarian crisis' since we think they may be central to understanding the peculiarities of Mexican deindustrialization.

While falling domestic demand did not cause the demise of woolen textiles, the invasion of foreign textiles clearly did. That invasion was carried, in turn, by two forces. First, there may have been supply side problems in Mexico which served to erode competitiveness at home. Second, and much more famous, there was the rapid, factory-based productivity advance in Britain, which increased British competitiveness and lowered textile prices the world around, thereby crowding out cottage industry in Mexico and everywhere else in the world's periphery. The cost of British cottons fell by as much as 70\% between 1790 and 1812 (Salvucci 1987: 156; Gómez Galvarriato 2002: 36), driven by those productivity gains:

"A crude measure shows that the price of segunda inglesa [cheap English textiles] fell from 21 reales per vara in 1778 to 16 for distribution through Querétaro in 1791, to between 14 and 16 in 1796, and to a low of 10 reales per vara in 1818. Not surprisingly, the obrajes of Mexico City and Querétaro, with costs at 18 reales per vara, could not withstand the competition" (Salvucci 1987: 158).

\footnotetext{
${ }^{13}$ Enrique Florescano (1969: 80) also argued that the agricultural crisis must have had severely damaging effects on obrajes and cotton cloth producers, by increasing the price of raw materials, by reducing the number of workers as a result of the frequent epidemics, and most of all by diminishing demand.
} 
According to Hamnett, the value of domestically produced textiles fell by one half between the 1800s and the 1820s (Hamnett 1980: 23). Compared with Mexico's key export product, silver, textile prices collapsed after around 1800 (Figure 2). This dramatic increase in the terms of trade provoked de-industrialization, although, as we shall see, its effects were cushioned by protectionist and other pro-industrial policies carried out by the first independent governments, as well as by persistent wage competitiveness produced by the non-tradable food producing sector.

\section{Domestic Textiles and Industry 1820-1879}

Latin American textile manufactures in general, and Mexican in particular, struggled against foreign imports at the start of the 19th century, apparently in a losing battle. In 1827, the English diplomat Henry George Ward saw a dismal future for Mexican textiles. He wrote:

"...until the end of the last century the value of cotton manufactures was estimated in five million dollars. Currently, they are gradually disappearing, as a result of the more abundant supply of European manufactures, and probably they will cease to exist in the course of a few years" (Ward 1985: 73).

There was clear evidence of Mexican de-industrialization when Ward was writing. Indeed, he must have been well aware of the fact that "in the capital of Oaxaca, where once 500 looms had clattered in the production of cotton cloth, a mere 50 were working in 1827" (Potash 1983: 27).

Ward's prediction did not materialize, and a decade later the industry was experiencing substantial growth. Textile artisans from Puebla and the merchants involved in the putting-out system were sufficiently powerful politically to obtain higher tariffs on textiles beginning in the early 1820s (Section 7). In 1820, Mexico had 6.5 million inhabitants and was the second largest population in the Western Hemisphere, after the United States (Gómez Galvarriato 1999: 196). 
Thus, in spite of the low income per capita of a large part of its population, ${ }^{14}$ Mexico had a relatively large domestic market in which to foster industrialization through protectionist policies.

During the 1820 s textile producers were united around the demand for protection, but debated the benefits of the mechanization. With the pro-industrialist Lucas Alamán at the head of the Ministry of Interior and Foreign Affairs in the early 1830's, the government began to support the establishment of mechanized factories through credit provided by the Banco de Avío, a development bank that supported industrialization, of which more will be said in Section 7.

From 1835 onwards, mechanized textile mills began to be established in Mexico, and the industry grew at impressive rates during the following decade:

"These mills were established around the same time that the Lowell mills were built, and only twenty years after the first mechanized mill was established in the United States.

Brazil, the other precocious industrializer in Latin America, established its first mills in the 1840s. Yet, by 1853 it only had 8 mills with 4500 spindles while ten years earlier Mexico's textile manufacture included 59 mills with more than 100,000 spindles" (Gómez Galvarriato 1999: 192).

As in other places, mechanization of spinning preceded that of weaving, but, as time went by, weaving began to be gradually carried out in factories as well. Cotton textile factory production grew rapidly in the late 1830 s and early 1840 s rising from less than 30 thousand kilos of yarn produced in 1838 to more than 3.5 million kilos in 1843 (Table 4). After that date, growth in cotton textile production slowed down for several reasons: an increase in the terms of trade that took place after 1845; a high price of domestic raw cotton (due to very high tariffs); much larger levels of political and economic instability in the second part of the 1840 s due to foreign invasion and domestic civil war (Ponzio 2005b); and a reduction in the support that the government gave to the industry exemplified by the closure of the Banco de Avío in 1840 and a decrease in tariffs.

\footnotetext{
${ }^{14}$ Bernecker (1992: 56-8). In the late $18^{\text {th }}$ century, New Spain appears to have had the highest inequality in the pre-modern world (Lindert, Milanovic, Williamson 2006).
} 
Nonetheless, the textile industry continued to grow between 1843 and 1879 . The number of looms and spindles increased by 138 and $241 \%$ respectively during that period. Moreover, the average firm increased in size as measured by spindles (up 58\%) and looms (up 126\%). However, while the average Mexican mill in 1843 -- in terms of spindles per mill -- was not much smaller than the average United States mill in 1831 , by 1879 it was only $20 \%$ of the average American mill one year later. The Mexican cotton textile industry also modernized between 1843 and 1879 . While $37 \%$ of the mills in 1843 used men or mules as their source of power and only $3 \%$ ran on steam, by 1879 no textile mill operated with animal or human power and $64 \%$ employed steam power (Gómez Galvarriato 1999: 204-7).

Towards the end of our period, the growth of the industry was fostered by more liberal commercial policies, as we shall see below in Section 7. Moreover, the American Civil War had a positive effect on the Mexican cotton textile industry since it increased the price of international cotton manufactures. It also served to decrease the price of raw cotton in Mexico, as the Union blockade of the South forced the Confederates to channel cotton exports over the Mexican border (Gómez Galvarriato 1999: 210).

The growth of the Mexican textile industry between 1834 and 1879 contrasts sharply with the devastating de-industrialization that took place in most parts the poor periphery. Table 3 uses Paul Bairoch's data to show that while levels of per capita industrialization were only about $10 \%$ higher in the European core than in the Asia and Latin America in 1750, they were 30\% higher in 1800 , and 4.3 times higher in 1860 . The table also shows that it was not simply a matter of faster European industrialization over the century, since the per capita industrialization index in the periphery fell by about $15 \%$ between 1750 and 1800, and by $67 \%$ between 1800 and 1860 . There were powerful de-industrialization forces at work in Mexico and the rest of the periphery after $1750 .{ }^{15}$ However, Mexico underwent less dramatic de-industrialization up to 1860 than did

\footnotetext{
${ }^{15}$ De-industrialization in the 18th century was not an event confined solely to periphery colonies like Mexico, but even to the Iberian colonizers. "The competitiveness of Spanish manufacturing fell ... and
} 
Asia and the rest of Latin America, and underwent more dramatic 're-industrialization' in the mid-late $19^{\text {th }}$ century. These aspects of Mexican exceptionalism will get our full attention below.

\section{A Neo-Ricardian Model of Mexican Agricultural Productivity and De-Industrialization}

What were the domestic supply-side problems that might have diminished Mexican competitiveness with foreign manufactures? During the century before the Porfiriato, when foodstuffs for the working class (like corn and beans) were not traded internationally and when foodstuff expenditures represented a huge share of family budgets, agricultural productivity must have influenced manufacturing competitiveness, as Alexander Gerschenkron (1965) and W. Arthur Lewis (1978) argued long ago. After all, in a pre-industrial economy with relatively stable subsistence wages (Lewis 1954), any decline in agricultural productivity must have put upward pressure on food prices and thus also on nominal wages in every non-food sector, eroding Mexican competitiveness. This would have been manifested by rising food prices relative to other products, by falling profitability in manufacturing, and by a decline in its output. This story seems to work well in accounting for the spectacular demise of Indian and Ottoman manufacturing in the face of British competition after 1750 (Clingingsmith and Williamson 2005; Williamson and Yousef 2006). It has also been cited by Lewis (1978) as a cause of de-industrialization in the tropical periphery more generally. It has even been carried forward a century by Victor BulmerThomas who describes Mexico's food sector in 1910 as one of the most unproductive in Latin America, so unproductive that Mexico had to import food from the rest of world:

"Mexican yields for many domestic crops (e.g., maize) were among the lowest in all Latin America and far below those recorded in Australia, Canada, New Zealand, and the United States. The maize yield in Mexico just before the First World War was 8.5

Spain became more and more dependent upon the goods produced in other European countries" (Márquez 2002a: 5). Ever since Earl Hamilton (1934) wrote about the inflations following the import of American (mainly Mexican) silver, Dutch disease has been invoked to explain de-industrialization in Spain, and Mauricio Drelichman (2005) has now shown us how it worked. 
quintals per hectare, compared with 16.3 in the United States, 17.7 in Australia, 31.2 in

New Zealand, and 35.2 in Canada" (Bulmer-Thomas 1994: 126).

The reasons offered by Bulmer-Thomas for this food productivity failure include a lack of transportation infrastructure since the "railway age ... took a long time to reach Mexico"

(Bulmer-Thomas 1994: 127). If this was true of 1910, it must have been even more true of 1810 and before. Furthermore, the drag which poor agricultural productivity put on manufacturing competitiveness was almost certainly stronger in 1810 than in 1910. After all, food grains were internationally traded by 1910, making it possible for Mexico to import cheap food, so that an unproductive domestic agriculture would no longer put upward pressure on food prices and thus on nominal wages in import-competing manufacturing.

In order to formalize our intuitions about the relationship between relative prices and deindustrialization, we use a simple neo-Ricardian model (Clingingsmith and Williamson 2005). Consider a perfectly competitive economy in which there are three sectors: textiles, the importable $^{16}(\mathrm{~T})$, silver, the exportable $(\mathrm{S})$, and corn, the non-tradable ${ }^{17}(\mathrm{C})$. We assume that textiles and silver are traded in the world market and sell for the world prices $\mathrm{p}_{\mathrm{T}}$ and $\mathrm{p}_{\mathrm{S}}$, respectively, while $\mathrm{p}_{\mathrm{C}}$ is determined endogenously by local supply and demand. Labor (L) is mobile between all three sectors, is the only factor of production, and costs nominal wage w per unit. We abstract from capital and land for simplicity, but in any case we do not need either of them to make our point. Finally, when we talk about a decrease in $\mathrm{L}_{\mathrm{T}}$, we refer to this contraction in textile employment as strong de-industrialization, and when we talk about a decrease in $\mathrm{L}_{\mathrm{T}} / \mathrm{L}$, we refer to this contraction in the textile employment share as weak de-industrialization. Table 3, for example, has already been used to describe weak de-industrialization around the poor periphery between 1750 and 1913 .

\footnotetext{
${ }^{16}$ Textiles were the canonical import-competing activity in Mexico. First, they dominated import values. In the mid-late 18th century, textiles probably accounted for more than $90 \%$ of total import values (Stein and Stein 2003: 75, 368), and most of that was non-Spanish (ibid.: 416). See Table 2. Second, they employed by far the largest share of the industrial labor force.

${ }^{17}$ We use the words corn, Indian corn, and maize interchangeably.
} 
To create a link between agricultural productivity and wages in the textile sector, we follow Lewis $(1954,1978)$ in assuming that the real wage in corn units was constant, at least in the short run and medium term. The Lewis assumption may, of course, have been violated in the very long run, especially in the resource-abundant Americas, but all that we require is that it was quite sticky in the short run. The Lewis assumption implies the possibility of unemployment, so L represents employment rather than the population, which we denote by $\mathrm{P}$.

Suppose output in each sector is produced according to a Cobb-Douglas production function:

$\mathrm{Y}_{\mathrm{C}}=\mathrm{CL}_{\mathrm{C}}^{\alpha}$

$\mathrm{Y}_{\mathrm{S}}=\mathrm{SL}_{\mathrm{S}}^{\beta}$

$\mathrm{Y}_{\mathrm{T}}=\mathrm{TL}_{\mathrm{T}}^{\gamma}$

$\mathrm{C}, \mathrm{S}$ and $\mathrm{T}$ are technology parameters (or include the impact of fixed endowments, like land) and the elasticities $\alpha, \beta$, and $\gamma$ are all less than 1, insuring diminishing returns. The labor market is such that each individual will supply one unit of labor as long as the corn or maize wage $w / p_{C}$ is at or above the reservation price of 1 . We assume that there is no rationing of labor, so that $\mathrm{L}=$ $\mathrm{L}_{\mathrm{C}}+\mathrm{L}_{\mathrm{S}}+\mathrm{L}_{\mathrm{T}}<\mathrm{P}$. Perfect competition in each sector ensures through zero-profit conditions that labor demand will be given by:

$\mathrm{L}_{\mathrm{C}}=\left(\mathrm{p}_{\mathrm{C}} \mathrm{C} / \mathrm{w}\right)^{(1 / 1-\alpha)}=\mathrm{C}^{(1 / 1-\alpha)}$, since $\mathrm{p}_{\mathrm{C}}=\mathrm{w}$,

$\mathrm{L}_{\mathrm{S}}=\left(\mathrm{p}_{\mathrm{S}} \mathrm{S} / \mathrm{w}\right)^{(1 / 1-\beta)}$

$\mathrm{L}_{\mathrm{T}}=\left(\mathrm{p}_{\mathrm{T}} \mathrm{T} / \mathrm{w}\right)^{(1 / 1-\gamma)}$

If we assume that there is no technical change, the growth rates of labor demand are

$\mathrm{L}_{\mathrm{C}} *=0$

$\mathrm{L}_{\mathrm{S}}^{*}=-(1 / 1-\beta)\left(\mathrm{w}^{*}-\mathrm{p}_{\mathrm{S}}^{*}\right)$

$\mathrm{L}_{\mathrm{T}}^{*}=-(1 / 1-\gamma)\left(\mathrm{w}^{*}-\mathrm{p}_{\mathrm{T}}^{*}\right)$

Since the nominal wage is equal to the price of corn, employment in the corn sector is fixed. Growth in the own wage in either silver mining $\left(\mathrm{w} / \mathrm{p}_{\mathrm{S}}\right)$ or textile production $\left(\mathrm{w} / \mathrm{p}_{\mathrm{T}}\right)$ leads to a 
decline in the absolute number of workers employed there. Thus, strong de-industrialization results from an increase in the own wage in textiles. The own wage in either sector could increase due to a decline in the world price for its output. It could also increase if the price of corn rose, induced, for example, by some negative productivity shock to agricultural output.

The growth rate of the share of textile workers in total employment, our measure of weak de-industrialization, is:

$$
L_{T}^{*}-L^{*}=\frac{-1}{(1-\beta)(1-\gamma)}\left(\left[(1-\beta)\left(1-\theta_{T L}\right)\left(w^{*}-p_{T}^{*}\right)\right]-\left[(1-\gamma) \theta_{S L}\left(w^{*}-p_{S}^{*}\right)\right]\right)
$$

The shares of textile production and silver mining in total employment are given by $\theta_{\mathrm{TL}}$ and $\theta_{\mathrm{SL}}$, respectively. Thus, weak de-industrialization will result whenever the own wage in textiles is growing sufficiently fast compared to the own wage in silver and other commodity exports. Moreover, holding employment shares constant, weak de-industrialization will be most severe when the difference in own wage growth rates is largest, and this can only result when the external terns of trade booms $\left(\mathrm{p}_{\mathrm{S}}^{*}>\mathrm{p}_{\mathrm{T}}{ }^{*}\right)$, since, by assumption, $\mathrm{w}^{*}$ is everywhere the same in the domestic economy. How much the terms of trade has to rise depends on $\beta, \gamma, \theta_{\mathrm{TL}}$ and $\theta_{\mathrm{SL}}$. As it turns out, the condition that must be satisfied for weak de-industrialization is

$$
w^{*}-p_{T}^{*}>\frac{(1-\gamma) \theta_{S L}}{(1-\beta)\left(1-\theta_{T L}\right)}\left(w^{*}-p_{S}^{*}\right)
$$

To the extent that $\beta$ and $\gamma$ are similar, and that $\left(1-\theta_{\mathrm{TL}}\right)>\theta_{\mathrm{SL}}$, the ratio on the right-hand side will certainly be less than one. This implies that own wage growth in silver and other commodity exports would have to be even higher to counteract the weak de-industrialization effect of own wage growth in textiles. ${ }^{18}$ In short, we expect to see weak de-industrialization whenever own wage growth in textiles is positive, unless own wage growth in commodity exports is much greater (e.g. when the external terms of trade deteriorates dramatically). Own wage growth in

\footnotetext{
${ }^{18}$ How much higher? As a rough guide, in $1895 \theta_{\mathrm{SL}}=0.018$ (mining) and $\theta_{\mathrm{TL}}=0.115$ (manufacturing), so $\theta_{\mathrm{SL}} /\left(1-\theta_{\mathrm{TL}}\right)=0.02$ (Catão 1998: Table 11, 70), implying that $\mathrm{P}_{\mathrm{T}}{ }^{*}$ would have to exceed $\mathrm{P}_{\mathrm{S}} *$ by almost 50 times (sic!), an immense deterioration in the terms of trade.
} 
silver mining dampens the weak de-industrialization effect because it reduces $\mathrm{L}_{\mathrm{S}}$, which is in the denominator of our weak de-industrialization measure. As the share of the labor force employed in silver and other commodity exports increases, the greater the growth in the own wage in textiles needs to be to overcome growth of the own wage in silver and other commodity exports and thus for de-industrialization to ensue. We can also rewrite condition (11) to relate nominal wage growth to the terms of trade between textiles and silver.

$$
\frac{(1-\gamma) \theta_{S L}+(1-\beta)\left(1-\theta_{T L}\right)}{(1-\beta)\left(1-\theta_{T L}\right)} w^{*}>p_{T}{ }^{*}-p_{S}{ }^{*}
$$

Weak de-industrialization results when nominal wage growth, which deters production in both non-corn sectors, is sufficiently greater than the growth of the terms-of-trade favoring textiles, which encourages production in textiles over silver and other commodity exports. Thus, weak deindustrialization should have been most severe when nominal wage growth was strongest and when the terms of trade were shifting most strongly in favor of silver and other commodity exports.

In summary, the predictions of this neo-Ricardian model are: industrial employment $\left(\mathrm{L}_{\mathrm{T}}\right)$ will decrease if the own wage in textiles increases (strong de-industrialization); and the industrial employment share $\left(\mathrm{L}_{\mathrm{T}} / \mathrm{L}\right)$ will decrease if own wage growth in textiles increases sufficiently faster than the own wage growth in silver and other commodity exports (weak deindustrialization).

\section{Trends in Mexico's Terms of Trade 1750-1879}

A rise in the terms of trade for a primary product exporter implies a fall in the relative price of import-competing manufactures, the bigger the rise, the bigger the penalty to home manufacturers. The timing and magnitude of such secular terms of trade shocks should have a powerful influence on de-industrialization experience. Mexico's increasing reliance on imported 
manufactures meant that as the world price of textiles, specifically, and manufactures, more generally, fell, Mexico's terms of trade improved, unless, of course, export prices fell too. Relative textile prices certainly fell dramatically the world around up to the 1850 s "as the Industrial Revolution drove down the unit cost of production in the exporting countries" and "as technological innovations shifted supply curves downward" (Bulmer-Thomas 1994: 43). But was it far less dramatic for Mexico?

\section{Terms of Trade Trends Before 1828}

For the period before 1828, we estimate Mexico's terms of trade trends by simply plotting the ratio of silver to textile prices, $\mathrm{P}_{\mathrm{S}} / \mathrm{P}_{\mathrm{T}}$. These estimates may be crude, but we doubt that terms of trade reality deviated much from what is plotted in Figure 2. As we have seen in Table 2, silver exports accounted for an enormous share of total exports and textiles accounted for a large share of total imports. While Figure 2 does not report it, we also calculated $\mathrm{P}_{\mathrm{S}} / \mathrm{P}_{\mathrm{M}}$ for the 1800 1828 period where the British export price index was used as a proxy for $\mathrm{P}_{\mathrm{M}}$. The two estimated terms of trade trends, $\mathrm{P}_{\mathrm{S}} / \mathrm{P}_{\mathrm{T}}$ and $\mathrm{P}_{\mathrm{S}} / \mathrm{P}_{\mathrm{M}}$, were highly correlated.

To the extent that $\mathrm{P}_{\mathrm{S}} / \mathrm{P}_{\mathrm{T}}$ is a good proxy for the Mexican eternal terms of trade, Figure 2 suggests a surprising moral. De-industrialization or Dutch disease forces could not have been very strong up to 1815 , since the relative price of import-competing textiles did not fall. Rather, it rose. True, the terms of trade jumped up by about $40 \%$ between 1815 and 1830 , but, as we shall see in a moment, it was stable afterwards (Figure 3), and especially so when compared to the rest of Latin America. Mexican exceptionalism indeed! Of course, while the price of importable textiles rose relative to exportable silver, textile prices may have fallen relative to non-tradables. The Dutch disease literature reminds us that the terms of trade between tradables and nontradables can be much more important than the external terms of trade, and Section 6 will explore this issue at length. For now, we simply note that Mexico failed to undergo the same kind of external terms of trade boom between 1750 and 1828 that the rest of the periphery did. 


\section{Terms of Trade Trends after 1828}

While primary product export prices were on a steep rise almost everywhere in the periphery in the first half of the 19th century, it appears that Mexico missed much of the boom (Figures 3, 4a, 4b). Over the full half century between 1828 and 1881, Leandro Prados estimates that Mexico's terms of trade did indeed rise, and at 1.4\% per annum (Prados 2004: 34-5).

However, all of that increase appears to have taken place after mid-century, since there was no upward trend in the Prados' terms of trade series between 1828 and the early 1840s (Figure 3). ${ }^{19}$ The Salvucci index of Mexican terms of trade with the US starts in 1825 and it confirms the Prados series. Indeed, the Salvucci series drops in the 1850s back to the late 1820s levels (Figure 3). How did Mexican terms of trade movements up to mid-century compare with the rest of the periphery, including the rest of Latin America? Figures $4 \mathrm{a}$ and $4 \mathrm{~b}$ document the secular boom in the terms of trade across the poor periphery (based on Williamson 2005, 2006b). Between 18201824 and 1850-1854, the terms of trade in Latin America rose at 1.4\% per annum, implying that Dutch disease forces were much weaker in Mexico than elsewhere in Latin America, perhaps even absent. The story is repeated when comparisons are made with other parts of the poor periphery: Egypt's terms of trade rose at 2.7\% per annum between 1820-1824 and 1855-1859; the terms of trade for the Ottoman Empire increased by 2.4\% per annum between 1815-1819 and 1855-1859; and the Indonesian terms of trade increased by $2.5 \%$ per annum between $1825-1829$ and 1865-1869. The least dramatic rise in terms of trade was in India between 1800-1804 and 1855-1859 (Clingingsmith and Williamson 2005), when it rose at about $0.5 \%$ per annum, but even this was more than in Mexico.

\footnotetext{
19 The true increase in Mexico's terms of trade may have been somewhat "larger because of the tradition of using export prices of a major exporter as a proxy for Latin American import prices - meaning that the statistics tend to understate the improvement in Latin America's [net barter terms of trade] by neglecting declining transport costs, which lower import prices" (Prados 2004: 80). But any downward bias would be shared by other regions in the periphery, so it should not affect any comparisons.
} 
What accounts for the very weak terms of trade boom in Mexico? It cannot be explained by a less dramatic fall in import prices $\left(\mathrm{P}_{\mathrm{M}}\right)$, since every member of the poor periphery imported much the same products (dominated by factory-made textiles). Rather, the explanation lies with export prices $(\mathrm{Px})$, namely, silver prices were stable during a period when other primary product prices soared.

In summary, it looks like the globalization-induced forces of de-industrialization were relatively weak in Mexico between independence and the Porfiriato. ${ }^{20}$ Thus, domestic manufactures should have been in a strong position relative to the rest of a poor periphery where de-industrialization was so dramatic. Whether their competitive position was strong enough to repel invading foreign manufactures is, of course, another matter entirely.

\section{Wage Competitiveness and Other Forces}

\section{Food Productivity and Wage Competitiveness}

It appears that de-industrialization forces were less pronounced in Mexico than in the rest of the poor periphery. Part of the explanation lies with the much weaker Mexican terms of trade boom, price trends which minimized the penalty which import-competing manufacturing had to absorb. But were there other underlying causes of this Mexican exceptionalism? One possibility might have been relatively stable agricultural productivity, an event which would have kept the price of non-tradable foodstuffs from rising too fast. We are not denying that agricultural productivity and living standards were low in Mexico, or even that there were no agricultural crises over those 150 years. We are only suggesting that without some secular deterioration in agricultural labor productivity, there would have been less upward pressure on the nominal wage

\footnotetext{
${ }^{20}$ Given these very modest terms of trade trends facing Mexico up to mid-century, it is hard to see how Bulmer-Thomas could conclude that "the case for basing comparative advantage on primary-product exports was strong" for Mexico at this time (Bulmer-Thomas 1994: 82).
} 
from this source, and import-competing manufacturing would have had a better chance of maintaining its wage competitiveness with foreign producers. What are the facts?

Let us start with the trend in relative commodity prices. Figure 5 plots $\mathrm{P}_{\mathrm{M}} / \mathrm{P}_{\mathrm{C}}$ and $\mathrm{P}_{\mathrm{X}} / \mathrm{P}_{\mathrm{C}}$, that is, the price of the tradables $\left(\mathrm{P}_{\mathrm{X}}\right.$ and $\left.\mathrm{P}_{\mathrm{M}}\right)$ relative to the key non-tradable $\left(\mathrm{P}_{\mathrm{C}}\right)$. These relative price trends trace out two distinct epochs. First, there was a dramatic decline in the relative price of tradables in the 60 or 70 years up to the Insurgencia and independence. This decline penalized both mining $\left(\mathrm{P}_{\mathrm{X}}\right)$ and textiles $\left(\mathrm{P}_{\mathrm{M}}\right)$, helping to contribute to de-industrialization by pulling resources out of manufacturing (and mining) and in to agriculture. Note that the external terms of trade $\left(\mathrm{P}_{\mathrm{X}} / \mathrm{P}_{\mathrm{M}}\right)$ did not rise over this period (Figure 3), so it was not a source of deindustrialization. But the rise in the price of corn relative to silver and textiles was a deindustrialization source, and it looks like it was powerful. How powerful depended on what was happening in England, India and elsewhere, something we shall explore below. In any case, it is obvious that we need to know a lot more about the forces that pushed up corn prices during this epoch. ${ }^{21}$ The second epoch begins when that secular decline flattened out and turned around after the 1810s. Over the half-century before the Porfiriato, there were cycles but no trend. There was a rise in $\mathrm{P}_{M} / \mathrm{P}_{C}$ and $\mathrm{P}_{\mathrm{X}} / \mathrm{P}_{\mathrm{C}}$ up to around 1850 , a trend that favored both mining and industry.

Figures 2 and 3 show that the post-1810s were also years of rising external terms of trade (albeit, much more modest than elsewhere in the poor periphery), events that penalized Mexican manufacturing and contributed to de-industrialization (albeit, much more modestly than elsewhere in the poor periphery). But trends in the internal terms of trade with agriculture had the opposite influence, and it looks like it may have dominated.

Next, what happened to the corn price of textiles $\left(\mathrm{P}_{\mathrm{T}} / \mathrm{P}_{\mathrm{C}}\right)$ in Mexico relative to its main competitor, England? England was undergoing impressive improvements in agricultural productivity at this time, events that should have cushioned the fall in $\mathrm{P}_{\mathrm{T}} / \mathrm{P}_{\mathrm{C}}$ there, kept the

\footnotetext{
${ }^{21}$ Florescano's (1969) extensive work on agricultural crises in Mexico has blazed the trail, but even his work focused on consequences rather than causes.
} 
upward pressure on the nominal wage modest, and, therefore, maintained English wage competitiveness. Did it, at least compared to Mexico? Figure 6 plots $\mathrm{P}_{\mathrm{T}} / \mathrm{P}_{\mathrm{C}}$ for England and Mexico. The result is surprising: after about 1800, the relative price of textiles fell faster in England than it did in Mexico! Thus, while the rise in corn prices tended to lower the relative price of textiles in both countries, the corn price rise was bigger in England. Note that the explanation for this cannot be faster productivity growth in English factories (although it certainly was faster), since textiles were internationally traded and textile prices moved the same way the world around. After all, England had to share her productivity gains with the rest of the world by a fall in output price. Thus, the explanation must lie with productivity events in agriculture, where the most important non-tradable commodity was produced. The fact that the relative price of textiles fell (the relative price of corn rose) faster in England than it did in Mexico is especially notable when compared with India where a collapse in agricultural productivity after the mid-late $18^{\text {th }}$ century produced a spectacular rise in the relative price of grains, generated immense upward pressure on the nominal wage and contributed to diminished wage competitiveness in textiles (Clingingsmith and Williamson 2005). Domestic forces in agriculture contributed powerfully to Indian de-industrialization in the century after 1750. Not so for Mexico. While a lagging agriculture pushed up the relative price of foodstuffs in England, India and Mexico, it was far less dramatic in Mexico. Since all three countries were competing with the rest of the world for textile market shares at home and abroad, Mexico appears to have been relatively favored by a more modest rise in $\mathrm{P}_{\mathrm{C}}$. Of course, the fact that Britain took the technological lead in textiles gave it a big edge in world markets. But the point of Figure 6 is that there were other (domestic) forces that offset the British de-industrialization impact on Mexico.

Figure 7 shows quite clearly that there were other forces at work eroding Mexican grain wages since they fell quite steeply from the mid- $18^{\text {th }}$ century until the $1810 \mathrm{~s}$. The downward trend in real wages just before independence speaks badly for the impact of late colonial conditions on the working poor, and the upward trend after about 1820 speaks well for the impact of 
independence on them. That pre-1820 fall should have strengthened wage competitiveness in textiles, while the post-1820 rise should have eroded it, at least to the extent that productivity growth in Mexican textiles was modest compared with England. Indeed, Figure 8 shows that while the own wage in textiles $\left(\mathrm{w} / \mathrm{P}_{\mathrm{T}}\right)$ was very stable up to the early $1830 \mathrm{~s}$, it doubled from then to the 1850s. If we are looking for evidence of domestic de-industrialization forces, we have found it here in the three decades or so between the 1820s and 1850s. Even more telling is the comparison with England. From 1751 to about $1820, \mathrm{w} / \mathrm{P}_{\mathrm{T}}$ drifted slightly downwards at about the same rate in both countries. Thus, while Mexico may have lost its competitive edge by lagging behind in adapting modern technology, it did not make matters worse by losing more of its competitive edge by a rise in the own wage. Furthermore, between 1820 and 1840, Mexican wage competitiveness improved relative to England, after which Mexico lost all that it had gained.

\section{Why Couldn’t Mexican Manufactures Compete Even More Effectively?}

Was Mexico's inability to compete more effectively with foreign producers before the 1820 s, and perhaps even before the 1850 s, due to the fact that Mexican wages were too high (even though their growth rates were not)? Bulmer-Thomas believes that this was not the case. In fact, he argues that wages were kept low by the practice of "providing workers with access to land in exchange for their labor ... These workers, known as peones acasillados in Mexico, were often virtually outside the money economy, for their payment was in kind rather than cash" (Bulmer-Thomas 1994: 91). The assertions of Bulmer-Thomas to the contrary, the use of peones acasillados might suggest instead that labor costs were too high to begin with, and that the practice was meant to increase domestic competitiveness by lowering wages. In any case, the more likely story is that domestic manufacturing (only $11.5 \%$ of total Mexican employment in 1895: Catão 1998) paid what the economy-wide labor market demanded and it was low labor productivity in agriculture that produced high nominal wages in textiles, something that was still true in 1910 (Clark 1987). 
Mexico and the rest of Latin America had a comparative advantage in primary products because they were relatively abundant in land and natural resources compared to Europe, and they had a comparative disadvantage in manufactures because they were relative scarce in labor compared to Europe. Thus, import-competing textiles and other manufactures should have faced heavy competition from European imports, just as Europe should have faced heavy competition from American grains, fish, metals, dyes and other resource-intensive products. At the end of his recitation of this point, Bulmer-Thomas adds the curious remark that "labor shortages persisted and contributed to the slow growth of exports" (1994: 91). If this was true of exports, why was it not even more true of labor-intensive, import-competing manufacturing, like textiles?

Another explanation offered for Mexico's inability to compete is the low quality of its labor and the culture of its labor market: "In the largest republics (Brazil and Mexico) the primary-education system remained woefully inadequate, forcing employers to rely on a work force with virtually none of the attributes required for technical progress and innovation" (Bulmer-Thomas 1994: 102). This claim assumes that textile production required a lot of skilled labor, something other authors, like Gregory Clark (1987), have questioned at length. Indeed, before the 1840s and the great mass emigrations to the New World, New England firms hired unskilled (but literate) native-born girls, while afterwards they hired unskilled (and illiterate) European immigrants. Since the New England example can be easily multiplied by reference to early factory-based textile development in Catalonia, Japan, India and even Britain, one can easily be sympathetic with a rejection of the low-labor-quality hypothesis as it applied to Mexico.

Alternatively, it has been suggested that "Mexican cotton manufacture suffered from technological [backwardness], which limited its capacity to supply the market and vitiated its ability to compete" (Hamnett 1980: 13). Salvucci continues with the comment that "productivity gains [associated with the new technologies] were limited to driving labor harder" (Salvucci 1987: 156). This sounds very much like Clark's “culture-of-the-labor-market thesis” (Clark 1987) whereby Mexico was unable to compete more effectively because the culture of Mexican labor 
markets did not allow the introduction of the hard driving new technologies. While domestic producers certainly faced some severe competitive disadvantages due to poor labor quality and technological backwardness, the literature suggests that the main reason for its relative demise was the increasing productivity abroad which induced a relative decline in manufacture's prices world-wide. To that extent, Mexican de-industrialization must have depended on when and how much the relative price of manufactures fell. The most dramatic de-industrialization should have occurred when the relative price of textiles and other manufactures was falling most dramatically, and that was before and after the 1820-1850 epoch, not during.

Gómez-Galvarriato adds politics and policy to the explanations for Mexican deindustrialization and for troubles in domestic textiles. Even after accounting for the many reasons why Mexico was unable to compete with foreign producers between 1820 and 1850, GómezGalvarriato argues that domestic textiles were not necessarily inherently uncompetitive, they just needed support from the government and a stable political environment in which to develop. According to this view, the Mexican government failed to take the steps needed to protect domestic industry, so that textile producers were not able to compete with imports. If, however, the government had moved to subsidize and protect the textile sector, it would have had a chance to develop the skills and efficiency necessary to compete with foreign imports after the subsequent removal of the tariff wall. This infant industry view certainly had become very popular with Alexander Hamilton's followers in the United States and with Frederick List's followers in Germany (Williamson 2006a). Support for it in Mexico comes from the fact that when the government there finally did take an interest in protecting and developing textiles, the industry did show strong signs of resisting import competition. Only "when political instability was briefly surmounted during the 1830 s and 1840 s, [did] the mechanization of the industry finally take place" and it occurred with the "support of government policies that gave [the sector] both the necessary protection and the financial support required, through the creation of a development bank: the Banco de Avío" (Gómez Galvarriato 2002: 52-5). 
Many scholars share this infant industry view. After all, without active intervention private interests would have had little incentive to invest in local industry given that foreign competition already dominated the market. Thomson feels that Mexico was in a position to modernize the cotton textile industry just prior to 1810 , before the flood of foreign imports. But once foreign competition grew too intense, merchants were reluctant to invest in restructuring the cotton textile industry:

"Demand for New Spain's cotton cloth became ever more volatile as a result of trade liberalization (comercio libre) within the Empire (increasing competition from Catalan cottons), increased contraband from without, Spain's involvement in the Napoleonic wars, and the licensing of neutral powers to trade directly with the Indies (chiefly, the United States)" (Thomson 1991: 267-8).

In other words, only a deliberate government program could have forced Mexican textiles to modernize; economic agents were not going to do it alone given the costs, uncertainty and risks. According to this view, protective tariffs starting in the 1820 s, and subsidies to mechanization starting in the 1830 s, were central to improving manufacturing competitiveness and offsetting the de-industrialization forces coming from abroad.

\section{Tariffs and Other Pro-Industrial Policies}

Mexican exceptionalism can be explained in part by modest terms of trade gains and weak Dutch disease effects. It can also be explained in part by the maintenance of its wage competitiveness from 1750 to the 1820 s, although that advantage evaporated over the four decades that followed. What about policy? Did tariffs consistently protect Mexican manufacturing from foreign competition? This possibility offers an especially promising explanation for Mexican exceptionalism since independence gave it the autonomy to choose tariff 
and industrial policies that colonial and/or dependent Asia and the Middle East could not (Williamson 2006a).

\section{Early Anti-Industrial Policy}

Some time ago, Robert Potash (1983) noted that early tariffs were designed primarily to increase government revenue instead of directly protecting domestic manufacturers, and this has been confirmed by many scholars since. For example, "the first law to regulate the foreign trade of the new Mexican Empire" passed December 15, 1821 imposed an ad valorem tax of $25 \%$ on all imports, regardless of their nature (Potash 1983: 13). The primary goal was to generate revenue, an interpretation supported by the fact that imported cotton textiles were not taxed at higher rates than other goods. Bulmer-Thomas also stresses that the motivation behind early Mexican tariffs was the need to generate revenue, rather than a desire to protect infant industries (Bulmer-Thomas 1994: 33). This view has been confirmed more generally for all of Latin America before the 1840s (Coatsworth and Williamson 2004a, 2004b; Williamson 2006a).

What is harder to explain, however, is the government's decision to prohibit a small number of items from being imported altogether, especially since "of the nine categories of excluded items, three were related to the ... manufacture of cotton [textiles]: cotton, cotton yarn up to weight number sixty, and cotton ribbon were barred from importation" (Potash 1983: 14). These prohibited items were mostly inputs for textile production. Indeed, raw cotton accounted for two-thirds of the total cost of cotton cloth while cotton yarn accounted for an even higher share (Clark 1987: 144). Obviously, this policy could hardly have helped the domestic producer since it lowered the effective rate of protection on textiles, perhaps even erasing its protective impact entirely. And since prohibition didn't generate any tariff revenue, such policies also failed to augment government coffers. 
Why did Mexico pursue these anti-industrial policies? It is, of course, possible that such polices were used simply to satisfy cotton-growing interests. ${ }^{22}$ It is also possible that the early tariffs were just the result of bad policy: that is, although the government may have wanted to help domestic textile manufacturing, they chose the wrong policy to do so. Either inference is consistent with the fact that other policies were more protectionist, including the fact that domestic cotton and woolen textiles were exempted from the $4 \%$ increase in the sales tax (up from 8 to 12\%) which was imposed on foreign textiles (Potash 1983: 15). Still, if it was mistaken policy, why didn't they learn from their mistakes? Domestic cotton prices rose up through the 1840 s - partially because of the prohibitions, and partially because of crop failures, labor shortages (Potash 1983: 134) and the unsuitable climate for growing the cotton needed for mechanical spinning (Thomson 1991: 287). To make matters worse, the increase in raw cotton prices led the government to grant licenses for the import of raw cotton, which in turn led to a monopoly for raw cotton suppliers. The predictable result was an "inadequate, irregular and costly supply of raw cotton became a major obstacle preventing the cotton textile industry from ... competing successfully with imports" (Thomson 1991: 287). If it was not mistaken policy but rather a transparent effort to reward cotton-growing interests, surely there were less damaging ways to achieve the same end.

\section{The Gradual Move to Pro-Industrial Protection}

Mexican tariff policies became more obviously protectionist when Guadelupe Victoria became president in 1824 . Victoria eliminated the $12 \%$ duty on foreign goods and replaced it with a federal impost, the derecho de internación, a real duty of " 18 3/4\% of the value of imported articles ... levied when they left the port of entry for any interior destination" (Potash 1983: 20). Moreover, state governments were allowed to impose a 3\% tax

\footnotetext{
${ }^{22}$ Raw cotton was grown extensively in Mexico, but it was not competitive in world markets. Thus, behind tariffs and prohibitions domestic cotton prices were higher than world prices.
} 
“(derecho de consumo) on foreign goods sold within their respective jurisdictions.

Imported merchandise thus paid a series of duties, state and federal, which totaled $513 / 8$ percent of their appraised value. Domestic textiles, in contrast, were subject only to the state alcabala of 8 percent" (Potash 1983: 21).

Under the tariff act of 1827 , a single ad valorem tax of $40 \%$ was placed on all imports, an effective strategy in terms of short term revenue collection as well as offering high protection for domestic manufactures.

Puebla's strategic location on the road between Mexico City and the port of VeracruzMexico's major trading port and where most taxes to foreign trade were collected—gave Puebla textile producers greater political clout than their number would have justified. Yet their demand for a prohibition of ordinary cloth imports had to be counterbalanced with the loss of fiscal resources that measure would have generated..$^{23}$ Thus, until 1829, the government did not comply with their demands for the prohibition on ordinary cloth imports. Although the government set relatively high tariff barriers, they were not enough to ease the difficulties of Puebla's textile producers, and social unrest increased. In December 1828, two riots of unprecedented scale and duration developed in the city of Puebla (Thomson 2002: 292-3), generating a shift in policy, With the rise of Vicente Guerrero, the government began to encourage actively the development of domestic industry and shifted away from the strictly revenue generating policies of the previous decade. On May 22, 1829, Guerrero signed into law a bill prohibiting the importation of coarse cotton and wool textiles - a measure unambiguously designed to protect domestic industries. Thus, "for the first time since independence, an outright ban was placed on the entry of inexpensive cotton textiles" (Potash 1983: 31). Of course, there was a big gap between legislated prohibition and smuggled reality. Indeed, by the 1840 s there was a widespread

\footnotetext{
${ }^{23}$ Between 1825 and 1835 more than half of the federal government's income came from import duties, and ordinary cotton cloth represented about $32 \%$ of total import value in 1826 and $46 \%$ in 1827 (Thomson 2002: 288).
} 
contraband trade and smuggled European cottons were displacing Mexican textiles (Salvucci 1987: 154). The size of this contraband trade was not trivial.

\section{First Best Principals: Subsidies and the Move to Mechanization in the 1830s}

The replacement of Guerrero by Anastasio Bustamente in 1830 marked a shift in the tactics but not in philosophy. Indeed, this new administration moved from what economists now call second best methods for encouraging better industrial performance to first best methods, that is, from tariffs to direct subsidy. This was done by dropping the prohibitions on cotton textile imports, imposing modest tariffs in their place, and using a portion of the revenue to subsidize the textile industry. This industrial strategy was illustrated most clearly with the creation of the Banco de Avío in October 1830, the state development bank funded by tariff revenues which granted loans for the purchase of industrial machinery, particularly in textiles (Potash 1983: 3945). The goal of the bank was to replace rather than preserve the inefficient handicrafts industries: "The Banco de Avío was the first to stipulate that industrial companies should receive loans and machinery, the first, in short, that fixed the establishment of the factory system as its goal" (Potash 1983: 46).

Potash thinks that the Banco de Avio accomplished its objective: ${ }^{24}$ "the bank contributed directly to the establishment of some half-dozen spinning and weaving factories" and helped make possible the rapid development of a modernized cotton textile industry in the decade 18351845 (Potash 1983: 125), which we have described in Section 3.

These assessments of the Mexican textile industry in the 1840 s are relatively positive. Other authors are less sanguine. Thomson, for example, argues that while domestic manufactures could produce rough cotton cloth on a large scale by the 1840 s, they could not compete with foreign imports by providing cloth of finer quality. Because of its confinement to the lower

\footnotetext{
${ }^{24}$ However, it may be of interest to note that the bank was officially dissolved in 1842 because of a lack of capital, losses from war, political interference, and default on outstanding loans.
} 
quality textiles, Thomson thinks that domestic production had already exhausted effective domestic demand by 1840. In fact, he claims that overproduction had become a problem. Accepting those assumptions, it follows that the only way to have increased output would have been to export to foreign markets or to improve the quality and range of production for the domestic market. Thomson argues that Mexican producers were not able to do either since their costs were too high (Thomson 1989: 76). No doubt all of this is true, but it hardly distinguished Mexico from any other textile-producing country competing with Europe. Indeed, it was even true of US textile manufacturing in the 1840s (Bils 1984; Harley 1992), Catalonia between the 1830s and the 1860s (Rosés 1998; Thomson 2005), and late Meiji Japan (Clark 1987).

Similarly, Gómez Galvarriato points to the low quality of Mexico's human capital as an inherent restraint on the textile industry's ability to mechanize (as does Bulmer-Thomas when describing earlier periods). "The low literacy rates that prevailed ... were indeed a reason for the slow industrial development of Latin America during the 19th century. It placed a constraint on industrial development by limiting the availability of the "skilled" workers the new industry required, making them scarce and expensive. Moreover, it set a huge barrier on the innovation capacities of the industry and its possibilities of adapting better techniques" (Gómez Galvarriato 2002: 58). While this argument may apply to Mexico, it is not clear how it would help explain Mexican exceptionalism. It bears repeating that while skilled labor was certainly scarce in Mexico, things were no better anywhere else in the periphery, including the Ottoman Empire, Russia, India and the rest of the poor periphery. And if Mexican labor was of such low quality, why did the textile industry survive foreign competition better than elsewhere in the poor periphery?

Potash's optimistic assessment of the impact of the Banco de Avío and the stage of Mexico's textile industry in the 1840 s is eroded still further by evidence that he himself cites. The government issued a decree in March 1837 banning the importation of foreign yarn and tejidos ordinarios de algodón (ordinary cotton textiles which would compete against the domestic 
products). Another tariff act was passed in 1843 which excluded all cotton cloth having less than thirty threads and placed an ad valorem tariff of $30 \%$ on imports, up from $25 \%$. The list of prohibited goods was also extended by some 180 items. These protective measures introduced in the late 1830 s and early 1840 s do not suggest a healthy and flourishing industry, but rather one in trouble, lobbying its government for yet more protection. Still, one should set this policy response in comparative perspective. Tariff policy in the rest of the autonomous periphery was equally, if not more, protectionist. For example, US northern manufacturing interests had lobbied to raise tariffs to about $52 \%$ on dutiable imports in 1830 , before an angry export-oriented South demanded a compromise at a lower, but still high range of 30 to $40 \%$ on dutiable imports (Irwin 2003: 13-14). Things were much the same in Australia, New Zealand and Canada (Williamson 2006a).

While imports were always a significant threat to domestic producers, the fact of the matter is that imports during the 1830 s and early 1840 s did not rise. Whatever were the inefficiencies of Mexican textile firms, they were not enough to shut them down, and tariff policy surely had something to do with that fact. ${ }^{25}$

\section{Tariffs Policy after 1850}

Dawn Keremitsis (1972) continues the story of Mexican tariff policies where Potash leaves off by describing the rise of the liberals in the 1850 s and the consequent end of the protectionist philosophy that characterized the second quarter of the century. The political economy of conservative Lucas Alamán (the brain behind Banco de Avío) was replaced by a new view, proposed by Miguel Lerdo de Tejada, favoring the liberalization of trade by reducing tariffs

\footnotetext{
${ }^{25}$ In Thomson's words, "the plains of Mexico were far from being bleached by the bones of hand loom weavers" (Thomson 1991: 274). Thomson is, of course, paraphrasing Karl Marx (who seems to have paraphrased Sir William Bentinck) on Indian de-industrialization. To state the obvious, British India did not have the tariff autonomy that a newly independent Mexico had, and free trade, not protection, ruled there.
} 
and the promotion of Mexico's comparative advantage in mining, agriculture and other primary products.

There was a substantial reduction in the tariffs on cotton manufactures in 1856 (Cosío Villegas 1932: 13, 43 and 92; Gómez Galvarriato 1999: 208). The ad valorem tariff on manta declined from $76.9 \%$ in 1855 to $23.1 \%$ in 1856 , only to increase again to $46 \%$ in $1878 .{ }^{26}$ However, liberal policies did not have the strong negative impact on the industry that the literature has generally assumed, since the prohibition on raw cotton was replaced by a duty that in ad valorem terms would have been of around $9.5 \% .{ }^{27}$ Thus, the effective rate of protection for the industry did not necessarily decline. Raw cotton accounted for between 48 and $72 \%$ of cotton textile costs. This implies that the Liberal tariff structure (which allowed the import of cheaper raw cotton) would have reduced the cost of domestic cotton textiles by between 23 to $35 \%$ : in the first case, profits would have fallen by $7.1 \%$, but in the second case, they would have increased by $4.8 \%{ }^{28}$

Was this dramatic shift in policy driven by weariness with the persistent intensity of foreign competition in the domestic textile market and by a continued decline in the relative price of textiles in world markets? True, commercial policy still protected domestic industry, despite the free trade rhetoric. Tariffs did fall in 1856 and although later increasing a little, did not come back to the pre-1856 levels, but the tariff structure became more complex, dividing products into more tariff categories, which rose from 293 in 1845 to 524 in 1856 and to 775 in 1872 . In addition, Mexican states with textile industries charged a duty, generally of $8 \%$, on manta crossing each state's border (both foreign and national) and an additional tax on foreign products,

\footnotetext{
${ }^{26}$ This calculation assumes a price of manta of 0.13 pesos per vara -- the price found for the years 1853 1859: Walker (1991); Keremitsis (1973); Butterfield (1859), and the average of the price reported by Keremitsis and the La Colonia Española (June 30,1877) for 1877. This price is more realistic than the price of 0.23 pesos assumed in Gómez Galvarriato (1999: 208). The duty was reduced from 0.10 in 1855 to 0.03 pesos per vara in 1856 . It was raised to $\$ 0.06$ pesos per vara in 1878 (Gómez Galvarriato 1999: Table 4).

${ }^{27}$ The duty was $\$ 1.5$ pesos per quintal, and the price of cotton is assumed to have been $\$ 15.87$ pesos per quintal (Alamán 1845: 48).

${ }^{28}$ Based on Bazant (1964) and Gómez Galvarriato (1999: 210). This also assumes a reduction in the price of raw cotton from $\$ 34$ to $\$ 17.37$ pesos per quintal (Gòmez Galvarriato 1999: 208).
} 
that for the state of Puebla was of 14\%.. (Keremitsis 1972: 697, 700). . Still, import prohibitions were abolished in 1856 - a recognition that smuggled goods generate no tax revenue. In short, it appears that the liberal tariff policies after 1856 were not necessarily worst (and perhaps even better) for industrial development than the protectionist tariff policies of the previous period. ${ }^{29}$

Was this dramatic shift in policy driven by weariness with the persistent intensity of foreign competition in the domestic textile market and by a continued decline in the relative price of textiles in world markets? True, commercial policy still protected domestic industry, despite the free trade rhetoric. Tariffs did fall slightly in 1856 and 1872, but the number of products paying duties rose from 293 in 1845 to 524 in 1856 and to 775 in 1872. In addition, Mexican states with textile industries raised their tax on foreign goods, generally with an $8 \%$ duty on manta crossing each state's border (Keremitsis 1972: 697, 700). Still, import prohibitions were abolished in 1872 - a recognition that smuggled goods generate no tax revenue. To further encourage importers to obey the law, tariffs were lowered after 1872.

Before we conclude that foreign imports could compete more effectively with domestic industry in 1872 than in 1852 , we need to say a word about the effective rate of protection for cotton textiles. Raw cotton accounted for between 48 and $72 \%$ of cotton textile costs. This implies that the Liberal tariff structure (which allowed the import of cheaper raw cotton) would have reduced the cost of domestic cotton textiles by between 23 to $35 \%$ and increased profits rates between 2 and 14\% (Bazant 1964; Gómez Galvarriato 1999: 210). In short, it appears that the liberal tariff policies after 1872 were better for industrial development than the protectionist tariff policies in $1852 .{ }^{30}$

\footnotetext{
${ }^{29}$ The issues are even more complex than this section suggests. For example, the elimination of domestic geographic barriers to trade - especially with the introduction of the railroads - exposed domestic producers to greater foreign competition, raising their lobbying efforts for protection, efforts which were successful (Coatsworth and Williamson 2004a, 2004b).

${ }^{30}$ The issues are even more complex than this section suggests. For example, the elimination of domestic geographic barriers to trade - especially with the introduction of the railroads - exposed domestic producers to greater foreign competition, raising their lobbying efforts for protection, efforts which were successful (Coatsworth and Williamson 2004a, 2004b).
} 


\section{Mexico in a Comparative Mirror}

Imports satisfied a significant part of the total Mexican textile demand in the $1870 \mathrm{~s}$. Mexico imported 40 million square meters of cloth in 1879, compared with 60 million square meters produced domestically. That is, foreign textile imports claimed $40 \%$ of the Mexican market. Yet, these same data imply that domestic producers were able to claim $60 \%$ of the local market, a fairly big number for a country that had been attacked by cheap European textiles for almost a century. Indeed, the figure for de-industrializing India was $35-42 \%$ in $1887,{ }^{31}$ the latter much lower than Mexico's $60 \%$ in 1879 . The de-industrialization evidence is even more dramatic for the Ottoman Empire where the share of domestic supply in total local consumption was only $11-38 \%$ in the early $1870 \mathrm{~s} .{ }^{32}$ Thus, despite the importance of foreign imports, the Mexican textile industry was doing fairly well towards the end of the 19th century (Keremitsis 1987: 703), at least compared with the rest of the periphery.

What accounts for this Mexican exceptionalism, compared with the rest of the poor periphery? This paper uses a neo-Ricardian three-sector model to help decompose the sources Mexican industrial experience between 1750 and 1879 in to three forces: first, the terms of trade and Dutch disease effects were weak -- compared with the rest of the periphery; second, based on a better relative agricultural productivity performance, Mexico maintained better wage competitiveness vis a vis the core -- compared with the rest of the periphery; and third, Mexico had the autonomy to devise effective policies to foster industry - compared with the rest of the periphery. We think the first was the most important of the three.

\footnotetext{
${ }^{31}$ The 1833 estimate and the smaller of the two 1887 estimates are from Roy (2000: 126). The larger 1887 estimate comes from Tomlinson (1993: Table 3.3, 107).

${ }^{32}$ Pamuk (1986: Table 1, 211). The wide range for 1870-1872 is due to assumptions about the treatment of yarn imports. Both estimates are, however, far lower than Mexico. We should add that the share of the domestic textile consumption satisfied by domestic producers was $95 \%$ in India in 1833 and $97 \%$ in the Ottoman Empire in the early 1820s. Immense de-industrialization forces indeed!
} 
What about after 1879? Stephen Haber thinks the true liftoff of Mexico's textile industry came only in the late 1880 s. A half century after Mexico's initial mechanization efforts, the 1888 industry was, according to Haber, still small and unproductive (although bigger and more productive than elsewhere in the poor periphery). But in the decade that followed

"the industry more than doubled in size. By 1911, the industry had grown an additional 50 percent. Estimates of total factor productivity (TFP) growth ... indicate increases of between 1.5 percent (lower bound) and 3.3 percent (upper bound) per year. Labor productivity grew even faster ... between 3.0 and 4.7 percent per year" (Haber 2002: 78).

Such growth rates meant that Mexican textile producers had displaced most imported cloth by 1914 (Haber 2002: 11). The only foreign textiles still being imported were high quality, fineweave cloth.

What explains the timing and the pace of the lift off? Based on what we have learned about the century before the Porfiriato, it seems to us that there are two likely candidates: first, a secular change in world relative prices facing the Mexican economy, a change that no longer penalized local manufacturing, and textiles in particular; and second, a change in tariff policy. Graciela Márquez (2002b) has argued that it was the introduction of a modern pro-industrial policy, including a coherent structure of protection. Haber appears to agree: "In 1891 Mexico was using tariffs to protect the cotton textile industry" which perhaps would have otherwise been uncompetitive. "This meant high tariffs on competing goods and low tariffs on inputs. The tariff on imported cloth tended to be twice that of the tariff on imported raw cotton. The result was an effective rate of protection that varied from 39 to 78 percent" (Haber 2002: 16).

We do not deny that policy mattered, and that Mexico was leading the way in Latin America (e.g. Brazil and Chile a little later in the 1890s, and Colombia in the early 1900s). But what about world prices and the terms of trade? A good part of Mexican exceptionalism in the century before 1890 can be explained by a far weaker terms of trade shock compared to the rest 
of Latin America, Asia and the Middle East. Could the same be true of the half century after 1890? Figure 9 suggests the answer is most definitely yes. There we see that the Mexican terms of trade fell after the 1880 s much more sharply than it did elsewhere in the poor periphery.

Indeed, the Mexican terms of trade was cut in half between 1890 and 1902, twice as big as the rest of Latin America. The fall in the Mexican terms of trade implied a relative rise in the price of imported manufactures, an event which favored industrialization. Furthermore, the price of exports fell even more dramatically relative to non-tradables (Catão 1998). It seems to us that these relative price movements may have accounted for much of Mexican exceptional industrialization experience between the 1880 s and the Revolution. We intend to pursue these ideas in future work, and, once again, we will do so by comparing Mexico with the rest of the primary-product exporting periphery. 


\section{References}

L. Alamán (1843), México, Dirección de Agricultura e Industria, Memoria sobre el Estado de la Agricultura e Industria de la República en el año de 1843 (Mexico City: Imprenta de J. Lara).

L. Alamán (1846), México, Dirección de Agricultura e Industria, Memoria sobre el Estado de la Agricultura e Industria de la República en el año de 1845 (Mexico City: Imprenta de J. Lara).

D. Acemoglu, S. Johnson, and J. Robinson (2002), "Reversal of Fortune: Geography and Institutions in the Making of the Modern World Income Distribution," Quarterly Journal of Economics 117 (November): 231-94.

R. Allen, J. P. Bassino, D. Ma, C. Moll-Murata and J. L. van Zanden (2005),“Wages, Prices, and Living Standards in China, Japan, and Europe, 1738-1925.” Unpublished manuscript.

P. Bairoch (1982), "International Industrialization Levels from 1750 to 1980," Journal of European Economic History 11 (Fall): 269-333.

J. Baskes (2005), “Colonial Institutions and Cross-Cultural Trade: Repartimiento Credit and Indigenous Production of Cochineal in Eighteenth-Century Oaxaca, Mexico," Journal of Economic History 65 (March): 186-210.

J. Bazant (1964), "Estudio sobre la productividad de la industria algodonera mexicana en 18431845," Sobretiro del volumen VII de la Colección de Documentos para la Historia del Comercio Exterior (Mexico City).

W. L. Bernecker (1992), De Agiotistas a Empresarios. En torno a la temprana industrialización mexicana (siglo XIX) (Mexico City: Universidad Iberoamericana).

M. Bils (1984), "Tariff Protection and Production in the Early U.S. Cotton Textile Industry," Journal of Economic History 44 (December): 1033-45. 
V. Bulmer-Thomas (1994), The Economic History of Latin America Since Independence (Cambridge: Cambridge University Press).

E. Busto (1880), México, Secretaría de Hacienda, , Estadísticas de la República Mexicana, 3 vols. (Mexico City: Imprenta de Ignacion Cumplido).

L. Catão (1998), "Mexico and export-led growth: the Porfirian period revisited," Cambridge Journal of Economics 22 (January): 59-78.

L. Catão (2006), “Export Growth, the Exchange Rate, and Machinery Investment in Early Development: The Cases of Brazil and Mexico," IMF, Washington, D.C. (February). G. Clark (1987), “Why Isn’t the Whole World Developed? Lessons from the Cotton Mills,” Journal of Economic History 47 (March): 141-73.

D. Clingingsmith and J. G. Williamson (2005), “Mughal Decline, Climate Change, and Britain's Industrial Ascent: An Integrated Perspective on India's eighteenth and nineteenth Century De-industrialization,” NBER Working Paper 11730, National Bureau of Economic Research, Cambridge, Mass. (November).

J. H. Coatsworth (1990), "Decadencia de la Economía Mexicana, 1800-1860," in J. H. Coatsworth (ed.), Los Orígenes del Atraso (Mexico City: Alianza).

J. H. Coatsworth (1992), "Notes on the Comparative Economic History of Latin America and the United States," in W. Reinhard and P. Waldmann (eds.), Nord and Süd in Amerika (Rombach: Verlag).

J. H. Coatsworth (2003), "Mexico" in J. Mokyr (ed.), The Oxford Encyclopaedia of Economic History, vol. 3 (New York: Oxford University Press), pp. 501-7.

J. H. Coatsworth (2005), "Structures, Endowments, and Institutions in the Economic History of Latin America," Latin America Research Review 40, 3: 126-44.

J. H. Coatsworth and J. G. Williamson (2004a), "The Roots of Latin American Protectionism: 
Looking Before the Great Depression," in A. Estevadeordal, D. Rodrik, A. Taylor and A. Velasco (eds.), FTAA and Beyond: Prospects for Integration in the Americas (Cambridge, Mass.: Harvard University Press.)

J. H. Coatsworth and J. G. Williamson (2004b), “Always Protectionist? Latin American Tariffs from Independence to Great Depression," Journal of Latin American Studies 36, part 2 (May): 205-32.

D. Cosío Villegas (1932), La Cuestión Arancelaria en México: Historia de la Política Aduanal III (Mexico City: Ediciones del Centro Mexicano de Estudios Económicos).

R. Dobado and G. Marrero (2001), “Minería, crecimiento económico y costes de la Independencia en México," Revista de Historia Económica XIX (3): 573-611.

R. Dobado and G. Marrero (2005) “The "Mining-Led Growth" in Bourbon Mexico, the Role of the State and the Economic Cost of Independence," Global Economic History Network Conference, Istanbul.

J. de Vries (1984), European Urbanization, 1500-1800 (Cambridge, Mass.: Harvard University Press).

M. Drelichman (2005), “The curse of Moctezuma: American silver and the Dutch `disease,” Explorations in Economic History 42 (July): 349-80.

S. L. Engerman and K. L. Sokoloff (1997), "Factor Endowments, Inequality, and Differential Paths of Growth Among New World Economies," in S. Haber (ed.), How Latin America Fell Behind (Stanford: Stanford University Press), pp. 260-304.

J. R. Fisher (1985), Commercial Relations between Spain and Spanish America in the Era of Free Trade, 1778-1796, (Liverpool: Centre for Latin-American Studies, University of Liverpool).

J. R. Fisher (1993), El comercio entre España e Hispanoamérica 1797-1820, (Madrid: Banco de España, Servicio de Estudios).

R. Findlay and K. H. O’Rourke (2003), “Commodity Market Integration, 1500-2000,” in M. D. 
Bordo, A. M. Taylor and J. G. Williamson (eds.), Globalization in Historical Perspective (Chicago: University of Chicago Press).

E. Florescano (1969), Precios Agrícolas del Maíz y Crisis Agrícolas en México 1708-1810 (Mexico City: Era, republished 1986).

A. Gerschenkron (1965), Economic Backwardness in Historical Perspective (New York: Praeger).

A. Gómez Galvarriato (1999) “Industrial Development Under Institutional Frailty: The Development of the Mexican Textile Industry in the Nineteenth Century," Revista de Historia Económica 17 (Special Issue): 191-223.

A. Gómez Galvarriato (2002), "Manufacturing in Latin America from Colonial Times to 1850." Draft, prepared for V. Bulmer-Thomas, J. Coatsworth and R. Cortes Conde (eds.), Cambridge Economic History of Latin America Volume I (Cambridge: Cambridge University Press, forthcoming).

S. Haber (2002), “It Wasn’t All Prebisch's Fault: The Political Economy of Twentieth Century Industrialization in Latin America.” Unpublished, Stanford University.

E. J. Hamilton (1934), American Treasure and the Price Revolution in Spain (Cambridge, Mass.: Harvard University Press).

B. R. Hamnett (1980), “The Economic and Social Dimensions of the Revolution of Independence in Mexico, 1800-1824," Ibero-Amerikanisches Archiv 6 (1): 1-27.

C. K. Harley (1992), "International Compeitiveness of the Antebellum American Cotton Textile Industry," Journal of Economic History 52 (September): 559-84.

L. E. Harrison (1985), Underdevelopment Is a State of Mind: The Latin American Case (Cambridge, Mass.: Harvard University, Center for International Affairs).

A. von Humboldt (1822), Political Essay on the Kingdom of New Spain, trans. J. Black (London: Longman, Hurst, Rees, Orne and Brown, republished 1984). J. Inikori (2002), Africans and the Industrial Revolution in England (Cambridge: Cambridge 
University Press).

D. A. Irwin (2003), "New Estimates of the Average Tariff of the United Sattes, 1790-1820," NBER Working Paper 9616, National Bureau of Economic Research, Cambridge, Mass. (April).

D. Keremitsis (1972), “La Industria Textil Algodonera durante la Reforma," Historia Mexicana 21 (April-June): 693-723.

D. Keremitsis (1987), The Cotton Textile Industry in Porfiriato, Mexico 1870-1910 (New York: Garland Publishing).

H. Klein (1998), The American finances of the Spanish Empire (Alburquerque, New Mexico: New Mexico University Press).

La Colonia Española (Mexico City, various issues).

D. S. Landes (1998), The Wealth and Poverty of Nations (New York: Norton).

M. Lerdo de Tejada (1853), Comercio esterior de México desde la conquista hasta hoy (Mexico D. F.: Rafael y Rafael).

W. A. Lewis (1954), "Economic Development with Unlimited Supplies of Labour," Manchester School of Economic and Social Studies 22: 139-91.

W. A. Lewis (1978), The Evolution of the International Economic Order (Princeton, NJ: Princeton University Press).

P. H. Lindert, B. Milanovic, and J. G. Williamson (2006), “An Early Map of Pre-Industrial Inequality" (ongoing).

A. Maddison (2003), The World Economy: Historical Statistics (Paris: OECD).

G. Márquez (2002a), "Monopoly and Trade in Colonial Latin America." Paper given at the XIII International Economic History Conference, Buenos Aires (July).

G. Márquez (2002b), “The Political Economy of Mexican Protectionism, 1868-1911," PhD thesis, Harvard University (March).

México, Dirección General de Estadística (1857), Memoria 1857 (Mexico City). 
México, Dirección General de Estadística (1894), Anuario Estadístico 1893 (Mexico City).

M. Miño Grijalva (1983), "Espacio económico e industria textil: los trabajadores de Nueva

España, 1780-1810," Historia Mexicana 23 (April-June): 231-61.

M. Miño Grijalva (1993), La Protoindustria Colonial Hispanoamericana (Mexico City: El

Colegio de México).

M. Miño Grijalva (1998), Obrajes y Tejedores de Nueva España (Mexico City: El Colegio de México).

B. R. Mitchell (2003), International Historical Statistics: Europe 1750-2000 (Hampshire, UK:

Palgrave Macmillan, $5^{\text {th }}$ ed.)

S. S. Mohammed and J. G. Williamson (2004), "Freight Rates and Productivity Gains in British Tramp Shipping 1869-1950," Explorations in Economic History 41 (April): 172-203.

K. H. O’Rourke and J. G. Williamson (1999), Globalization and History (Cambridge, Mass.: Cambridge University Press).

Ş. Pamuk (1986), “The Decline and Resistance of Ottoman Cotton Textiles 1820-1913,” Explorations in Economic History 23 (April): 205-25.

Ş. Pamuk (1987), The Ottoman Empire and European Capitalism, 1820-1913: Trade, Investment and Production (Cambridge: Cambridge University Press).

C. A. Ponzio (2004), "Essays on the History of Economic Growth in Mexico," unpublished PhD thesis, Harvard University (June).

C. A. Ponzio (2005a), "Globalisation and Economic Growth in the Third World: Some Evidence from Eighteenth Century Mexico,” Journal of Latin American Studies 37 (August): 43767.

C. A. Ponzio (2005b), "Looking at the Dark Side of Things: Political Instability and Economic Growth in Post-Independence Mexico," unpublished manuscript.

R. A. Potash (1983), Mexican Government and Industrial Development in the Early Republic: The Banco de Avío (Amherst: University of Massachusetts Press). 
J. M. Pérez Hernández (1862), Estadisticas de la República Mexicana (Guadalajara: Tipografia del Gobierno a cargo de Antionio de P. González).

L. Prados de la Escosura (2004), "The Economic Consequences of Independence in Latin America.” Draft, prepared for V. Bulmer-Thomas, J. Coatsworth and R. Cortes Conde (eds.), Cambridge Economic History of Latin America Volume I (Cambridge: Cambridge University Press, forthcoming).

J. R. Rosés (1998), “The Early Phase of Catalan Industrialisation, 1830-1861,” unpublished PhD thesis, European University Institute (October).

T. Roy (2000), The Economic History of India, 1857-1947 (Oxford: Oxford University Press).

R. J. Salvucci (1987), Textiles and Capitalism in Mexico: An Economic History of the Obrajes, 1539-1840 (Princeton: Princeton University Press).

R. J. Salvucci (1992), Textiles y capitalismo en México: una historia económica de los obrajes, 1539-1840 (Mexico City: Alianza).

R. J. Salvucci (1997), “Mexican National Income in the Era of Independence, 1800-1840,” in S. Haber (ed.), How Latin America Fell Behind (Stanford: Stanford University Press).

S. J. Stein and B. H. Stein (2003), Apogee of Empire: Spain and New Spain in the Age of Charles III, 1759-1789 (Baltimore: Johns Hopkins Press).

G. P. C. Thomson (1985), "Protectionism and Industrialization in Mexico, 1821-1854: The Case of Puebla," in C. Abel and C. M. Lewis (eds.), Latin America, Economic Imperialism and the State (Dover, New Hampshire: Athlone Press).

G. P. C Thomson (1989), “Traditional and Modern Manufacturing in Mexico, 1821-1850,” in R. Liehr (ed.), América Latina en la época de Simón Bolívar (Berlin: Colloquium Verlag).

G. P. C. Thomson (1991), “Continuity and Change in Mexican Manufacturing, 1800-1870," in J. Batou (ed.), Between Development and Underdevelopment (Geneva: Librairie Droz).

G. P. C. Thomson (2002), Puebla de los Angeles: industria y sociedad de una ciudad mexicana, 1700-1850 (Mexico City: Benemérita Universidad de Puebla). 
J. K. L. Thomson (2005), "Explaining the 'take-off' of the Catalan cotton industry," Economic History Review LVIII (4): 701-35.

B. R. Tomlinson (1993), The Economy of Modern India, 1860-1970 (Cambridge: Cambridge University Press).

H. G. Ward (1985), México en 1827 (Mexico City: Fondo de Cultura Económica).

J. G. Williamson (1990), Coping with City Growth during the British Industrial Revolution (Cambridge: Cambridge University Press).

J. G. Williamson (2005), “Globalization, De-industrialization and Underdevelopment in the Third World Before the Modern Era," Figuerola Lecture, Carlos III University, Madrid (October 6).

J. G. Williamson (2006a), “Explaining World Tariffs 1870-1938: Stolper-Samuelson, Strategic Tariffs and State Revenues," in R. Findlay, R. Henriksson, H. Lindgren and M. Lundahl (eds.), Eli F. Heckscher, 1879-1952: A Celebratory Symposium (Cambridge, Mass.: MIT Press).

J. G. Williamson (2006b), Globalization in the Poor Periphery Before the Modern Era (Cambridge, Mass.: MIT Press).

J. G. Williamson and T. Yousef (2006), "De-Industrialization Around the Pre-Modern Periphery: Egypt and the Ottoman Empire 1790-1913,” ongoing. 


\section{Appendix}

This appendix describes the sources of the wage and price data used in the analysis underlying the general equilibrium price dual model in Section 4, and the empirical analysis in Sections 5 and 6. Every price and wage series was converted in to common currency (typically pesos, and 8 reales $=1$ peso) and quantity units before linking them together for the 1750-1878 series. The following definitions and notation, taken from Section 4, are used in this Appendix:

$\mathbf{P x}=$ export price

Pm $=$ import price

$\mathbf{P c}=$ price of non-tradable grains (corn)

$\mathbf{P t}=$ price of import-competing manufacturing textiles (usually cotton and usually cloth)

$\mathbf{W}=$ nominal wage rate (daily, urban unskilled peón)

\section{Mexican textile prices 1751-1878 (Pt: Appendix Table, col. 1)}

1.1 1751-1777: We were unable to find any useable Mexican textile price quotes before 1778 . Since Spain was the main foreign supplier of textiles to Mexico (e.g. Nueva España), and since transport costs on the westward leg of the Atlantic trade were quite stable during mid $18^{\text {th }}$ century peacetime years, we take these prices series as proxies for Mexican Pt 1751-1777. We use an average of two Spanish cloth price series: Palencia (now in Castilla y Leon) textile prices, where Ptp is the average of linen, and two woolen price series (Moreno 2006: made available by the author); and Madrid textile prices, where Ptm is the average of estameña, sayal and paño blanco prices (Hamilton 1947: supplied by Joan Roses. See also section 4.1 below.)

1.2 1777-1878 Benchmarks: Here we use scattered wholesale price quotes for manta cloth per vara from Guadalajara, Mexico City, Puebla and Oaxaca to establish prices in benchmark years = series A. These benchmark years are: multi-observation averages for 1777 (3), 1831 (3), 1836 (4), 1843 (4), 1850 (3), and 1867 (4); and single observations for 1787, 1803, 1809, 1810, 1827, $1834,1835,1839,1842,1845,1857,1859$ and 1867. Sources for prices: 1777, 1787, 1803, 1810, 1827, 1834, 1836, 1842, 1843, 1847, and 1867 (Thomson 2002: 373); for 1781, 1782 and 1804 (Miño 1998: 231 and 235); for 1800, 1835, 1836, 1839, 1843, 1845, 1847, 1853 (Walker 1991); for 1809, 1836, 1839, 1842, 1843, 1845 (Potash 1983: 163); for 1843 (Alamán 1843; Bazant 1964); for 1850 (Banco Nacional de Comercio Exterior S.A. 1959, 1965); for 1859 (Butterfield 1861); for 1867 (Herrera 1977: 38); for 1871 (The Two Republics, December 9, 1871: 2); for 1874-1877 (La Colonia Española, February 1, 1874, March 1, 1875, February 15, 1876 and June 30 1877); for 1877 (Keremitsis 1973: 71). Notes for prices: Prices are stated in pesos per vara. One piece of cloth may have measured between 30 and 36 varas, but we assumed the piece to be equal to 32 varas following Bazant (1964): 1 vara $=36$ inches $=0.8359$ meters. 1.3 1777-1878 Interpolations and Projections: The next step was to interpolate between the benchmark years.

1.3.1 1777-1827: For the period 1777-1827, we used the Ptp data for interpolations. Thus, for 1777-1787, 1787-1803, 1803-1809, and 1810-1827: (1) we computed a geometric (exponential) trend between the benchmark years in the A series; (2) we then computed \% deviations from geometric trend between same years in the Ptp series; finally, we applied the \% deviations from (2) to the trend in (1). Thus, we preserve the Mexican benchmarks and the implied trends between them, but infer (unobserved) short run movements between them from the volatility in the Spanish series. Prices for the following years were ignored since they were ones during which there was a war-induced shut down in trade: 1781, 1797-98, 1800-01, and 1805-06. 
Instead, we interpolated those war years. The year 1812 was retained since the shock was induced by the Insurgencia, not European conflict.

1.3.2 1827-1877: For the period 1827-1877, we interpolated using unit values of British cotton textile exports reported in the Parliamentary Papers $=$ Pgb. Thus, for 1827-31, 1831-34, 1836-39, 1839-42, 1843-50, 1850-57, 1859-67 and 1867-77: (1) we computed the geometric (exponential) trend between benchmark years in the A series; (2) we then computed \% deviations from the geometric trend between the same years in the Pgb series; finally, we applied the \% deviations from (2) to the trend in (1). Thus, we preserve the trends between Mexican benchmarks, but infer (unobserved) short run movements between them from the volatility in the British price series. For 1843-45 and 1857-59, we interpolate the middle year by using geometric trend between these years.

1.3.3 The 1878 observation is constructed by projection from the 1877 A observation, using series Pgb.

1.4 Linking yields a $\underline{\boldsymbol{P t}} \underline{\text { series }} 1750-1878(1828=100)$.

\section{Mexican grain prices 1750-1877 (Pc: Appendix Table, col. 2)}

2.1 Corn prices 1750-1810: Reales per fanega, wholesale prices quoted in Mexico City markets (Garner 1993).

2.2 Maize prices 1810-1833: Reales per fanega (estimated from Thomson 1989).

2.3 Maize prices 1833-1863: Reales per fanega, wholesale prices quoted in Comanja and Leon, annual averages (Brady 1988: 332).

2.4 1863-1877: We have prices for arroz, frijol and maize 1859-1877 (from Amilcar Challu's ongoing research on $18^{\text {th }}$ and $19^{\text {th }}$ century living standards in Mexico), but use only maize prices to be consistent with earlier corn and maize price series.

2.5 Linking yields a $\underline{\boldsymbol{P}}$ series 1750-1877 $(1828=100)$.

\section{Mexican unskilled, urban wages 1750-1860 (W: Appendix Table, col. 3)}

3.1 Peón obra wages 1750-1838: Reales per day, collected by Amilcar Challu for his ongoing research on $18^{\text {th }}$ and $19^{\text {th }}$ century living standards in Mexico. The data here refer to his "all Mexico -- peons, sobrestante, and official" series.

3.2 Peón obra wages 1838-1860: Reales per day, multiple observations taken from the records of convents, hospitals and other institutions. Also collected by Amilcar Challu.

3.3 Linking yields a $\underline{W}$ series $1750-1860(1828=100)$. While we are still searching for nominal wage rate data $1860-1878$, we have been unsuccessful thus far.

\section{Mexican prices of tradables 1750-1940 (Px, Pm and Px/Pm: Appendix Table, cols. 4 and 5)}

\subsection{0-1828:}

4.1.1 Pm 1750-1800: As a proxy for (unobserved) Mexican Pm, we used the average of the two Spanish textile price series, quoted for Palencia and Madrid. For Palencia (Ptp: 17501800), we took the average of linen, and two woolen, price series. We interpolate geometrically to fill in missing years. These three textile price series are highly correlated. For Madrid (Ptm: 1751-1800), we took the average of estameña, sayal and paño blanco prices to construct a Madrid cloth price (Bona 1868-1869: supplied by Hector Garcia). It turned out that since Ptm and Ptp were so highly correlated, we simply used the Madrid Ptm series as the proxy 1751-1800 (although 1750 was taken from the Palencia Ptp series, since the Madrid series starts with 1751).

4.1.2 Pm 1800-1828: As a proxy for (unobserved) Mexican Pm, we used the British export price index to proxy trends in the Mexican import price index (Mitchell 1962: p. 331). 
4.1.3 Px 1750-1828: Since silver was such a large share of export receipts, we used silver prices (pesos per gram of coined silver) to proxy Mexican export prices (Burzio 1956).

\subsection{Px, Pm and Px/Pm 1828-1940:}

4.2.1 Mexico 1828-1870: We rely on Prados (2004) and Salvucci (1987).

4.2.2 Mexico 1870-1940: Data underlying Catáo (2006).

4.2.3 Latin America 1810-1870: Data underlying Williamson (2005).

4.2.4 Latin America, Asia, Ottoman 1870-1940: Data underlying Williamson (2005)

4.3 Linking yields series 1750-1940 for $\underline{\mathbf{P x}}, \underline{\mathbf{P m}}$ and $\underline{\mathbf{P x} / \mathbf{P m}}(1828=100)$.

\section{Appendix References}

L. Alamán (1843), México, Dirección de Agricultura e Industria, Memoria sobre el Estado de la Agricultura e Industria de la República en el año de 1843 (Mexico City: Imprenta de J. Lara).

Recuadro de Nueva España, (México D. F.: Fondo de Cultura Económica). Fragment of Historia de México desde los primeros movimientos que prepararon su Independencia en elaño de 1808 hasta la época presente (México D. F.: J. Mariano Lara).

Banco Nacional de Comercio Exterior S.A. (1959), Los Industriales Mexicanos y el Comercio Exterior (1848-1852). Colección de Documentos para la Historia del Comercio Exterior de México III (Mexico City: Publicaciones del Banco Nacional de Comercio Exterior S.A.).

Banco Nacional de Comercio Exterior S.A. (1965), El Comercio Exterior y el Artesano Mexicano (1825-1830). Colección de Documentos para la Historia del Comercio Exterior de México Segunda Serie I (Mexico City: Publicaciones del Banco Nacional de Comercio Exterior S.A.)

F. J. Bona (1868-1869), Anuario administrativo y estadístico de la provincia de Madrid para el año de 1868 (Madrid: Tip. Del Hospicio).

D. Brading (1988), Haciendas y Ranchos del Bajío León 1700-1860 (Mexico: Grijalbo).

H. Burzio (1956), Diccionario de la moneda hispanoamericana (Santiago de Chile: Fondo Histórico y Bibliográfico José Toribio Medina).

C. Butterfield (1861), United States and Mexico: Commerce, Trade and Postal Facilities Between the two Countries, Statistics of Mexico (New York: J. A. H. Hasbrouck and Co. Printers, $2^{\text {nd }}$ ed.).

L. Catão (2006), "Export Growth, the Exchange Rate, and Machinery Investment in Early Development: The Cases of Brazil and Mexico," mimeo. Research Department, IMF (February 22).

R. L. Garner (1993), Economic Growth and Change in Bourbon Mexico (Gainsville, Florida: University of Florida Press).

E. J. Hamilton (1947), War and Prices in Spain (Cambridge, Mass.: Harvard University Press).

I. Herrera Canales (1977), El Comercio Exterior de México 1821-1875 (Mexico City: El Colegio de México).

D. Keremitsis (1973), La Industria Textil Mexicana en el Siglo XIX (Mexico City: SEP-Setentas).

La Colonia Española (Mexico City, various issues).

B. R. Mitchell (1962), Abstract of British Historical Statistics (Cambridge: Cambridge University Press).

J. Moreno (2006), "El nivel de vida en la España atrasada entre 1800 y 1936 . El caso de Palencia," Investigaciones de Historia Económica (4): 9-50.

L. Prados de la Escosura (2004), "The Economic Consequences of Independence in Latin 
America." Draft, prepared for V. Bulmer-Thomas, J. Coatsworth and R. Cortes Conde (eds.), Cambridge Economic History of Latin America Volume I (Cambridge: Cambridge University Press, 2006).

R. J. Salvucci (1987), Textiles and Capitalism in Mexico: An Economic History of the Obrajes, 1539-1840 (Princeton: Princeton University Press).

The Two Republics (Mexico City, various issues).

U.K. Parliamentary Papers, Return to an Order of the Honourable House of Commons. Various issues.

U.K. Parliamentary Papers, Mexican and South American Import Duties on British Yarns. Vol LXVIII, 1878, 622-746.

D.W. Walker (1991), Parentesco, negocios y política: la familia Martínez del Río en México, 1823-1867 (Mexico City: Alianza).

J. G. Williamson (2005), "Globalization, De-industrialization and Underdevelopment in the Third World Before the Modern Era," Figuerola Lecture, Carlos III University, Madrid (October 6). 


\begin{tabular}{|c|c|c|c|c|c|}
\hline 1750 & $\begin{array}{c}\text { (1) } \\
\text { Pt }\end{array}$ & $\begin{array}{l}\text { Appendix } \\
\text { (2) } \\
\text { Pc } \\
114.1\end{array}$ & $\begin{array}{c}\text { Table } \\
\text { (3) } \\
\text { W } \\
82.3\end{array}$ & $\begin{array}{c}(\mathbf{4}) \\
\mathbf{P x} \\
97.7\end{array}$ & $\begin{array}{c}\text { (5) } \\
\text { Pm }\end{array}$ \\
\hline 1751 & 56.0 & 52.2 & 81.7 & 97.7 & 140.4 \\
\hline 1752 & 60.2 & 22.1 & 81.0 & 97.7 & 150.9 \\
\hline 1753 & 64.7 & 27.1 & 80.4 & 97.7 & 162.2 \\
\hline 1754 & 68.7 & 28.0 & 79.8 & 97.7 & 172.2 \\
\hline 1755 & 67.1 & 42.0 & 78.3 & 97.7 & 168.4 \\
\hline 1756 & 64.8 & 41.7 & 78.1 & 97.7 & 162.5 \\
\hline 1757 & 69.2 & 27.3 & 77.9 & 97.7 & 173.4 \\
\hline 1758 & 69.3 & 34.6 & 77.7 & 97.7 & 173.8 \\
\hline 1759 & 66.9 & 42.1 & 75.8 & 97.7 & 167.8 \\
\hline 1760 & 65.0 & 49.8 & 73.9 & 97.7 & 162.9 \\
\hline 1761 & 62.6 & 52.5 & 75.8 & 97.7 & 156.9 \\
\hline 1762 & 58.0 & 42.7 & 77.7 & 97.7 & 145.5 \\
\hline 1763 & 61.9 & 26.5 & 77.7 & 97.7 & 155.1 \\
\hline 1764 & 65.4 & 31.2 & 77.7 & 97.7 & 163.9 \\
\hline 1765 & 65.6 & 33.0 & 77.7 & 97.7 & 164.6 \\
\hline 1766 & 64.8 & 35.9 & 77.7 & 97.7 & 162.4 \\
\hline 1767 & 62.3 & 29.6 & 77.7 & 97.7 & 156.1 \\
\hline 1768 & 64.8 & 30.5 & 77.7 & 97.7 & 162.5 \\
\hline 1769 & 65.8 & 36.3 & 77.7 & 97.7 & 165.0 \\
\hline 1770 & 66.9 & 55.9 & 77.7 & 97.7 & 167.8 \\
\hline 1771 & 67.1 & 59.0 & 77.7 & 97.7 & 168.4 \\
\hline 1772 & 65.4 & 72.0 & 77.7 & 98.5 & 164.0 \\
\hline 1773 & 66.6 & 57.5 & 77.7 & 99.2 & 166.9 \\
\hline 1774 & 63.8 & 48.6 & 77.4 & 99.2 & 159.9 \\
\hline 1775 & 63.2 & 38.2 & 77.4 & 99.2 & 158.5 \\
\hline 1776 & 64.8 & 58.3 & 74.2 & 99.2 & 162.5 \\
\hline 1777 & 66.2 & 39.7 & 75.8 & 99.2 & 165.9 \\
\hline 1778 & 66.2 & 43.0 & 77.4 & 99.2 & 171.1 \\
\hline 1779 & 63.6 & 50.2 & 78.9 & 99.2 & 172.9 \\
\hline 1780 & 57.5 & 60.4 & 79.2 & 99.2 & 166.4 \\
\hline 1781 & 56.9 & 56.9 & 84.0 & 99.2 & 171.9 \\
\hline 1782 & 56.2 & 47.6 & 83.8 & 99.2 & 168.2 \\
\hline 1783 & 55.2 & 37.2 & 83.7 & 99.2 & 177.2 \\
\hline 1784 & 54.5 & 54.1 & 80.7 & 99.2 & 183.3 \\
\hline 1785 & 57.3 & 108.9 & 78.6 & 99.2 & 189.6 \\
\hline 1786 & 56.1 & 176.6 & 78.6 & 99.2 & 194.8 \\
\hline 1787 & 52.0 & 85.7 & 77.1 & 100.0 & 189.0 \\
\hline 1788 & 51.1 & 70.3 & 75.7 & 100.0 & 185.1 \\
\hline 1789 & 51.6 & 114.3 & 78.0 & 100.0 & 190.4 \\
\hline 1790 & 45.3 & 63.1 & 79.2 & 100.0 & 173.6 \\
\hline 1791 & 46.2 & 74.1 & 77.4 & 100.0 & 175.7 \\
\hline 1792 & 52.7 & 48.8 & 77.7 & 100.0 & 192.4 \\
\hline 1793 & 51.4 & 59.8 & 77.7 & 100.0 & 192.7 \\
\hline
\end{tabular}




\begin{tabular}{|c|c|c|c|c|c|}
\hline 1794 & 54.4 & 95.2 & 77.6 & 100.0 & 202.0 \\
\hline 1795 & 57.6 & 59.3 & 77.5 & 100.0 & 211.7 \\
\hline 1796 & 57.9 & 61.2 & 77.4 & 100.0 & 227.0 \\
\hline 1797 & 57.4 & 75.3 & 77.4 & 100.0 & 253.3 \\
\hline 1798 & 56.9 & 78.5 & 77.4 & 100.0 & 232.1 \\
\hline 1799 & 56.3 & 67.1 & 78.6 & 100.0 & 221.4 \\
\hline 1800 & 54.2 & 74.9 & 78.0 & 100.0 & 210.7 \\
\hline 1801 & 52.1 & 64.9 & 77.2 & 100.0 & 212.7 \\
\hline 1802 & 49.9 & 88.0 & 77.4 & 100.0 & 238.4 \\
\hline 1803 & 48.8 & 87.5 & 77.2 & 100.0 & 227.9 \\
\hline 1804 & 56.6 & 74.5 & 77.4 & 100.0 & 221.9 \\
\hline 1805 & 59.2 & 73.6 & 77.4 & 100.0 & 219.2 \\
\hline 1806 & 61.8 & 78.0 & 83.1 & 100.0 & 214.3 \\
\hline 1807 & 64.3 & 83.7 & 79.8 & 100.0 & 218.3 \\
\hline 1808 & 68.1 & 57.4 & 78.9 & 100.0 & 221.1 \\
\hline 1809 & 61.1 & 108.1 & 78.3 & 100.0 & 207.6 \\
\hline 1810 & 61.1 & 183.2 & 80.1 & 100.0 & 207.3 \\
\hline 1811 & 62.2 & 123.1 & 76.9 & 100.0 & 212.1 \\
\hline 1812 & 63.4 & 124.3 & 76.0 & 100.0 & 207.4 \\
\hline 1813 & 64.6 & 90.9 & 86.1 & 100.0 & 200.3 \\
\hline 1814 & 65.8 & 130.3 & 93.5 & 100.0 & 193.5 \\
\hline 1815 & 67.1 & 125.5 & 105.6 & 100.0 & 176.1 \\
\hline 1816 & 68.3 & 176.9 & 94.7 & 100.0 & 166.5 \\
\hline 1817 & 69.6 & 162.6 & 102.7 & 100.0 & 152.2 \\
\hline 1818 & 70.9 & 92.1 & 99.4 & 100.0 & 159.6 \\
\hline 1819 & 72.3 & 180.5 & 92.9 & 100.0 & 151.9 \\
\hline 1820 & 73.7 & 99.2 & 99.4 & 100.0 & 137.8 \\
\hline 1821 & 75.1 & 110.0 & 99.1 & 100.0 & 131.3 \\
\hline 1822 & 76.5 & 78.9 & 98.8 & 100.0 & 120.7 \\
\hline 1823 & 77.9 & 118.4 & 98.5 & 100.0 & 116.7 \\
\hline 1824 & 79.4 & 89.7 & 97.9 & 100.0 & 113.8 \\
\hline 1825 & 80.9 & 89.7 & 91.4 & 100.0 & 123.4 \\
\hline 1826 & 82.4 & 89.7 & 90.8 & 100.0 & 108.7 \\
\hline 1827 & 84.0 & 94.8 & 107.4 & 100.0 & 102.5 \\
\hline 1828 & 100.0 & 100.0 & 100.0 & 100.0 & 100.0 \\
\hline 1829 & 82.6 & 105.2 & 84.0 & 100.0 & 105.8 \\
\hline 1830 & 90.2 & 52.6 & 107.4 & 100.0 & 110.7 \\
\hline 1831 & 100.5 & 49.0 & 93.5 & 100.0 & 109.7 \\
\hline 1832 & 73.3 & 157.8 & 94.4 & 100.0 & 102.9 \\
\hline 1833 & 83.5 & 64.6 & 95.2 & 101.0 & 96.1 \\
\hline 1834 & 84.0 & 89.4 & 96.1 & 101.0 & 95.1 \\
\hline 1835 & 68.1 & 67.0 & 93.5 & 101.0 & 98.1 \\
\hline 1836 & 70.9 & 50.2 & 92.9 & 101.0 & 118.4 \\
\hline 1837 & 63.9 & 41.6 & 80.7 & 101.0 & 121.4 \\
\hline 1838 & 66.4 & 38.3 & 78.6 & 102.0 & 110.7 \\
\hline 1839 & 62.0 & 38.7 & 78.6 & 102.0 & 105.8 \\
\hline 1840 & 69.8 & 50.2 & 78.6 & 102.0 & 101.9 \\
\hline 1841 & 70.1 & 65.0 & 78.6 & 101.0 & 101.0 \\
\hline 1842 & 53.5 & 48.8 & 76.7 & 100.0 & 99. \\
\hline
\end{tabular}




\begin{tabular}{|c|c|c|c|c|c|}
\hline 1843 & 54.7 & 23.9 & 74.9 & 101.0 & 92.2 \\
\hline 1844 & 50.3 & 40.2 & 75.1 & 100.0 & 90.3 \\
\hline 1845 & 40.5 & 62.2 & 75.4 & 100.0 & 94.2 \\
\hline 1846 & 37.2 & 70.8 & 75.6 & 101.0 & 97.1 \\
\hline 1847 & 33.9 & 43.0 & 75.9 & 101.0 & 101.9 \\
\hline 1848 & 29.2 & 43.0 & 76.1 & 101.0 & 89.3 \\
\hline 1849 & 31.1 & 46.0 & 76.4 & 102.0 & 83.5 \\
\hline 1850 & 31.1 & 49.2 & 76.6 & 103.0 & 95.1 \\
\hline 1851 & 31.2 & 52.6 & 76.9 & 102.0 & 86.4 \\
\hline 1852 & 29.6 & 45.0 & 77.1 & 104.0 & 87.4 \\
\hline 1853 & 28.0 & 49.3 & 77.4 & 104.0 & 96.1 \\
\hline 1854 & 32.6 & 50.7 & 77.6 & 104.0 & 104.9 \\
\hline 1855 & 29.5 & 49.3 & 77.9 & 104.0 & 101.9 \\
\hline 1856 & 29.4 & 40.6 & 78.1 & 104.0 & 97.1 \\
\hline 1857 & 33.2 & 33.5 & 78.4 & 104.0 & 107.8 \\
\hline 1858 & 30.0 & 45.3 & 78.6 & 105.1 & 98.1 \\
\hline 1859 & 29.3 & 61.2 & 78.6 & 104.0 & 101.9 \\
\hline 1860 & 31.8 & 82.8 & 78.6 & 108.1 & 99.0 \\
\hline 1861 & 31.8 & 111.9 & & 107.0 & 91.6 \\
\hline 1862 & 39.4 & 40.2 & & 108.1 & 102.6 \\
\hline 1863 & 48.7 & 105.2 & & 108.1 & 114.0 \\
\hline 1864 & 58.9 & 106.5 & & 108.1 & 128.3 \\
\hline 1865 & 54.5 & 107.8 & & 108.1 & 109.6 \\
\hline 1866 & 56.4 & 145.5 & & 107.0 & 111.8 \\
\hline 1867 & 49.6 & 138.3 & & 106.0 & 87. \\
\hline 1868 & 43.6 & 131.4 & & 106.0 & 81. \\
\hline 1869 & 41.4 & 124.9 & & 106.0 & 75.8 \\
\hline 1870 & 36.5 & 118.7 & & 106.0 & 73.8 \\
\hline 1871 & 36.9 & 112.8 & & 106.1 & 73. \\
\hline 1872 & 38.5 & 107.2 & & 106.2 & 78. \\
\hline 1873 & 37.2 & 101.9 & & 104.8 & 78.5 \\
\hline 1874 & 31.4 & 96.8 & & 102.9 & 73. \\
\hline 1875 & 30.0 & 92.1 & & 100.1 & 74. \\
\hline 1876 & 32.6 & 87.5 & & 94.0 & 67. \\
\hline 1877 & 24.9 & 83.1 & & 97.4 & 60. \\
\hline 1878 & 25.8 & & & 89.6 & 55. \\
\hline
\end{tabular}


Table 1

Per Capita GDP Estimates, 1700-1870

(1990 international dollars)

\begin{tabular}{ccc}
\multicolumn{2}{c}{ Mexico } & $\begin{array}{c}\text { Maddison } \\
\text { Western Spain } \\
\text { Coatsworth } \\
\text { Europe }\end{array}$
\end{tabular}

1700

755

568

527

998

853

1800

755

566

759

1,257

1,204

1,008

1845

592

642

674

2,445

1,960

1,207

Source: Maddison (2003) and Coatsworth $(2003,2005)$. 


\section{Table 2}

Textile Imports/Imports and Silver Exports/Exports (\%) 1802-1872

$\begin{array}{lcc} & \text { Textiles } & \text { Silver } \\ 1802 & 72,9 & 63,7 \\ 1803 & 84,9 & 42,2 \\ 1804 & 53,0 & 56,3 \\ 1805 & 23,8 & 3,5 \\ 1806 & 39,4 & 36,5 \\ 1807 & 62,8 & 52,0 \\ 1808 & 50,4 & 56,4 \\ 1809 & 40,1 & 57,9 \\ & & \\ 1821 & 62,5 & 84,0 \\ & & \\ 1823 & 59,0 & 56,5 \\ 1824 & 68,1 & 62,2 \\ 1825 & 63,9 & 72,5 \\ 1826 & 63,9 & 77,6 \\ 1827 & 70,5 & 79,5 \\ 1828 & 58,6 & 85,5 \\ & & \\ 1856 & 59,9 & 96,3 \\ & & \\ 1872 & 52,0 & 80,1\end{array}$

Source: See Figure 1. 
Table 3

Per Capita Levels of Industrialization 1750-1953

\begin{tabular}{|c|c|c|c|c|c|}
\hline & 1750 & 1800 & 1860 & 1913 & 1953 \\
\hline European Core & 8 & 8 & 17 & 45 & 90 \\
\hline \multicolumn{6}{|c|}{ Asian and Latin American } \\
\hline Periphery & 7 & 6 & 4 & 2 & 5 \\
\hline China & 8 & 6 & 4 & 3 & 5 \\
\hline India & 7 & 6 & 3 & 2 & 5 \\
\hline Brazil & $\mathrm{Na}$ & na & 4 & 7 & 13 \\
\hline Mexico & $\mathrm{Na}$ & na & 5 & 7 & 12 \\
\hline Ratio Core/Periphery & 1.1 & 1.3 & 4.3 & 22.5 & 18 \\
\hline
\end{tabular}


Table 4 Growth in the Mexican Cotton Textile

Industry 1837-1879

\begin{tabular}{ccccc}
\hline Year & $\begin{array}{c}\text { No. of } \\
\text { Factories }\end{array}$ & $\begin{array}{c}\text { No. Active } \\
\text { Spindles }\end{array}$ & $\begin{array}{c}\text { Yarn } \\
\text { (tons) }\end{array}$ & $\begin{array}{c}\text { Cloth Pieces } \\
(1000 \text { 's })\end{array}$ \\
\hline 1837 & & & & 45 \\
1838 & & & 29 & 109 \\
1839 & & & 15 & 125 \\
1840 & & & 257 & 88 \\
1841 & & & 467 & 196 \\
1842 & & & 358 & 218 \\
1843 & 59 & 106,708 & 3,738 & 327 \\
1844 & & 112,188 & & 508 \\
1845 & 55 & 113,813 & 1,317 & 657 \\
1853 & & & 3,348 & 875 \\
$1850-1857$ & 48 & 119,278 & 3,351 & 727 \\
1862 & 57 & 133,122 & 3,615 & 1,259 \\
1879 & 89 & 253,594 & 2,925 & 3,255 \\
\hline \multicolumn{5}{c}{ Sources: Alamán (1843: Table 5); Alamán (1846: Tables 2, } \\
3, and 4); México, Dirección General de Estadistica (1857); \\
Pérez Hernández (1862: 136-9); Busto (1880); México, \\
Dirección General de Estadística (1894).
\end{tabular}



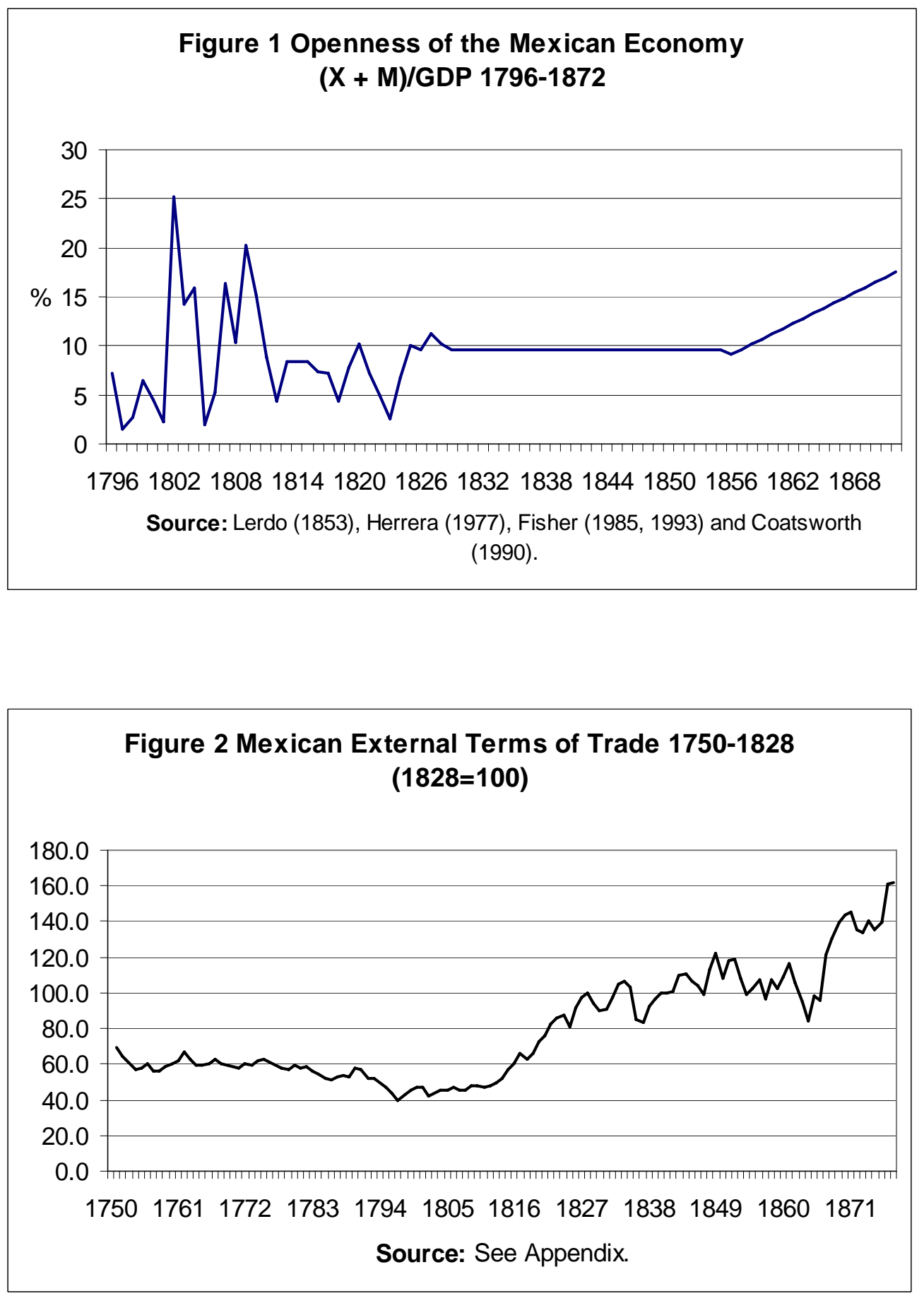

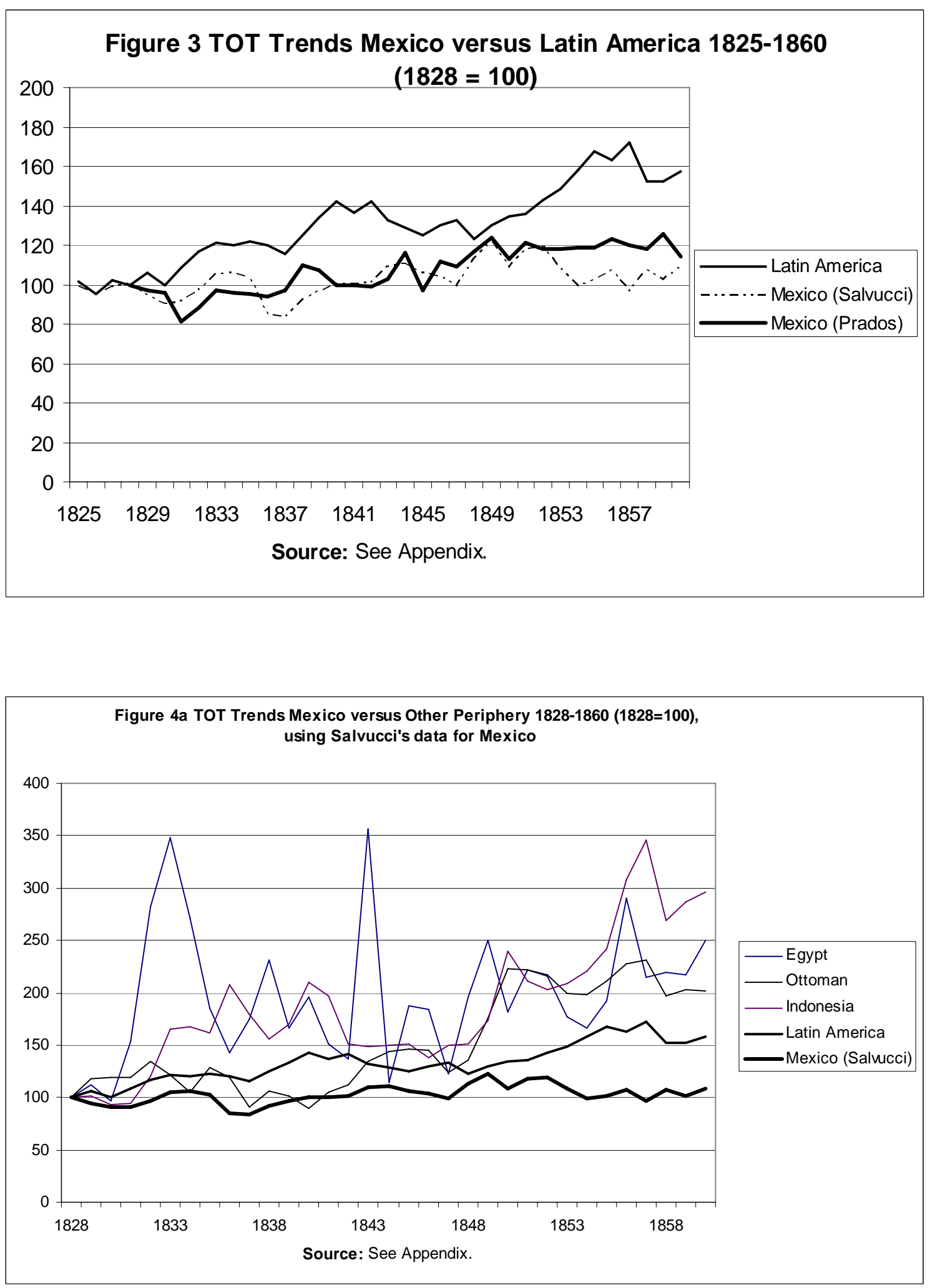

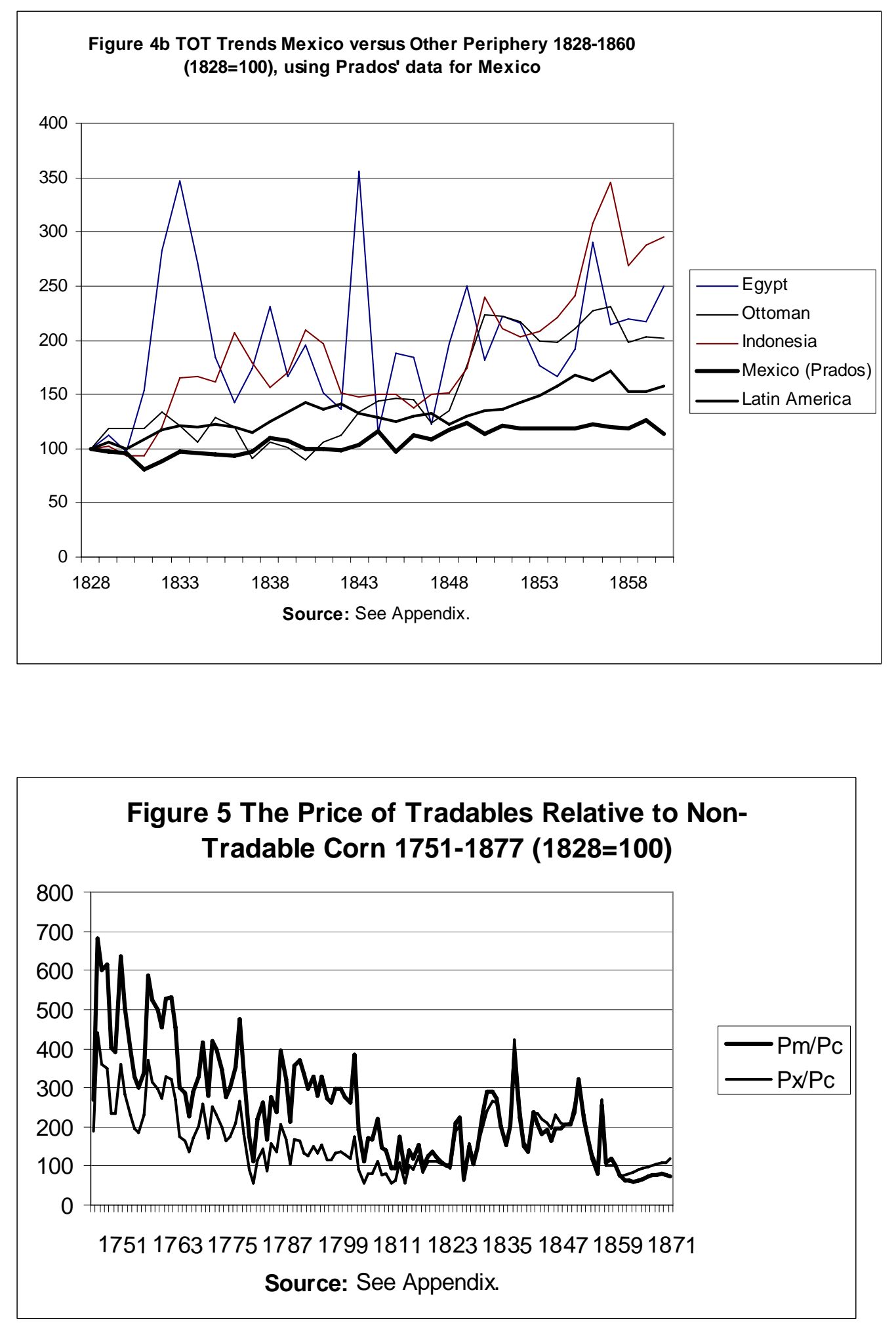

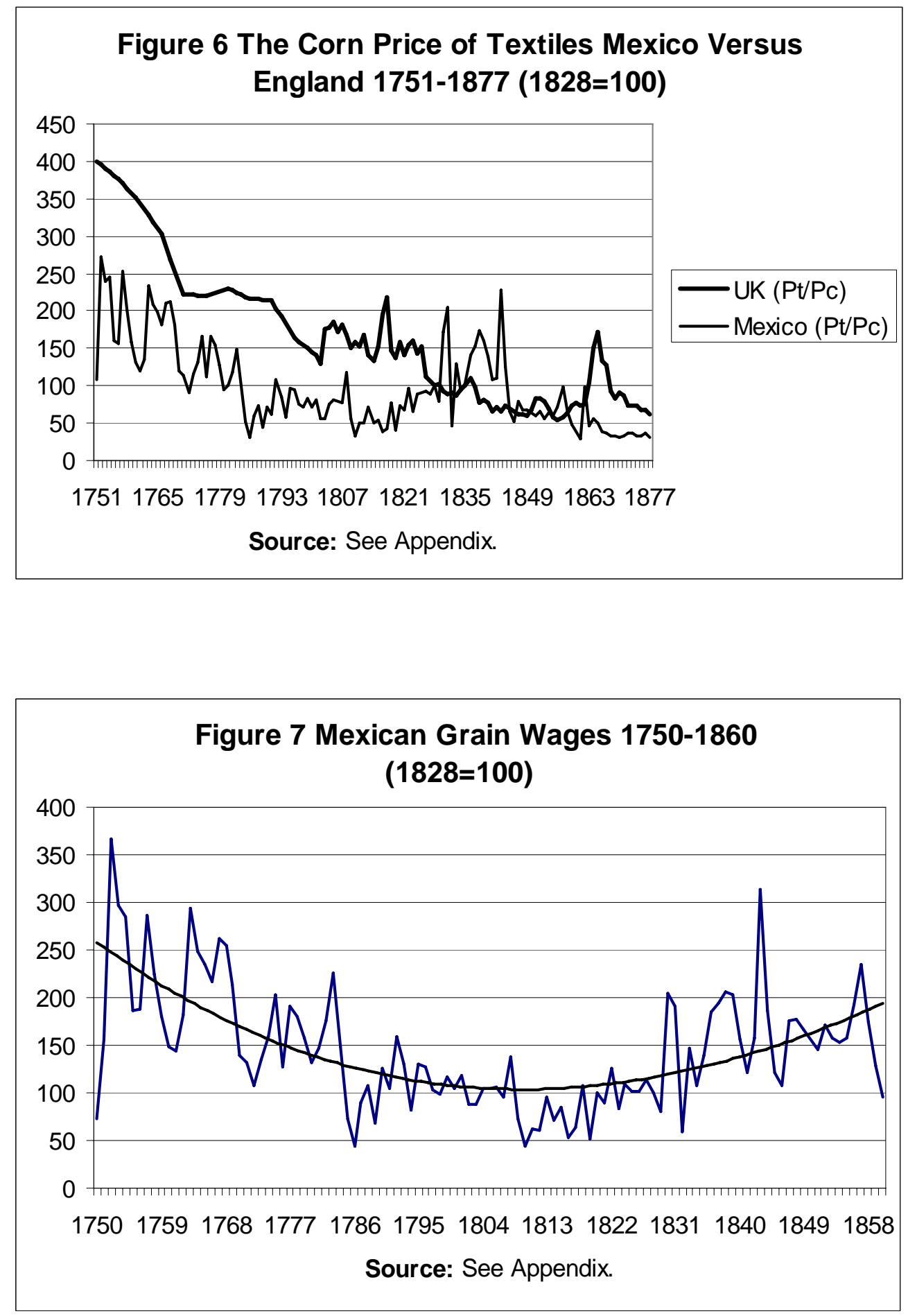

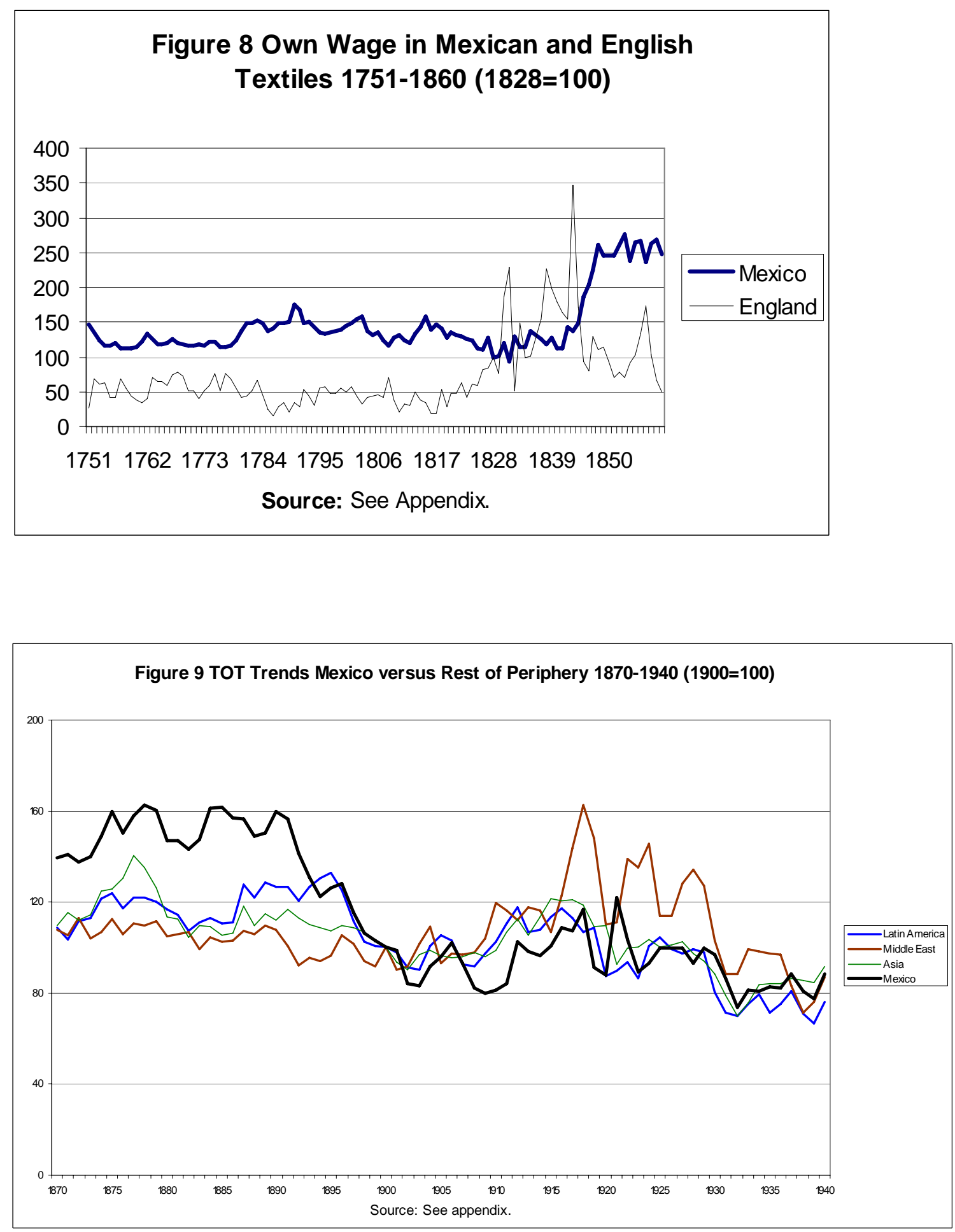